\title{
Developing two benchmark models for post-world war II residential buildings
}

\author{
Shady Attia ${ }^{\mathrm{a}, *}$, Ahmed Mustafa ${ }^{\mathrm{b}}$, Nicolas Giry ${ }^{\mathrm{a}, \mathrm{c}}$, Mathieu Popineau ${ }^{\mathrm{a}, \mathrm{d}}$, Mathilde Cuchet $^{\mathrm{a}, \mathrm{c}}$, \\ Numan Gulirmak ${ }^{\mathrm{a}}$ \\ a Sustainable Building Design Lab, Dept. UEE, Faculty of Applied Science, Université de Liège, Belgium \\ ${ }^{\mathrm{b}}$ Urban Systems Lab, The New School University, USA \\ ${ }^{\mathrm{c}}$ EPF Graduate School of Engineering, Montpellier, France \\ d ENSE3 Graduate School of Engineering, Grenoble, France
}

\section{A R T I C L E I N F O}

\section{Article history:}

Received 20 February 2021

Revised 17 April 2021

Accepted 21 April 2021

Available online 26 April 2021

\section{Keywords:}

Reference building

Single-family detached home

Energy audit

Energy efficiency

Energy use intensity

Temperate climate

\begin{abstract}
A B S T R A C T
In the context of the European carbon neutrality targets, building benchmarks are a key issue for the renovation of existing buildings. Although there are various benchmark methods for energy efficiency characterization, their application to the residential sector is still limited. This paper developed two building simulation models for post-world war II houses in Belgium based on data from post-occupancy measurements and field survey campaigns. The study reports the energy characteristics and occupancy profiled of detached single-family houses. An analysis of energy consumption (electricity and natural gas) and a walkthrough survey were conducted between 2016 and 2019. The benchmark model's validity has been further checked against public statistics and verified through model calibration and monthly energy bill comparison. Two reference models representing 633.702 post-WWII single-family houses in Belgium were created and validated. The first archetype has an average energy use intensity of $166 \mathrm{kWh} / \mathrm{m}^{2} / \mathrm{year}$ and represents detached single-family houses built between 1945 and 1969. The second archetype has an average energy use intensity of $155 \mathrm{kWh} / \mathrm{m}^{2} /$ year and represents detached single-family houses built between 1970 and 1990 . The paper provides a timely opportunity to evaluate the real performance of post-world war II most common archetypes concerning design assumptions and how building professionals can turn the energy performance gap challenge to their advantage. The findings on energy needs and intensity are useful for creating future renovation scenarios for similar archetypes in Western European countries.
\end{abstract}

(c) 2021 Elsevier B.V. All rights reserved.
Abbreviations: ANN, artificial neural networks; BPIE, Building Performance Institute Europe; BMS, building management system; CAV, constant air volume; $\mathrm{CDD}$, cooling degree days; CBECS, commercial buildings energy consumption survey; CIBSE, chartered institution of building services engineers; CO2, carbon dioxide; COP, coefficient of performance; CV(RMSE), coefficient of variation of the root mean square error; DHW, domestic hot water; EPBD, European energy performance of buildings directive; EU, European Union; EUI, energy use intensity; GDPR, general data protection regulation; HDD, heating degree days; HVAC, heating, ventilation and air conditioning; IAQ, indoor air quality; IEQ indoor environmental quality; MBE, mean bias error; MVHR, mechanical ventilation with heat recovery; nZEB, nearly zero energy building; nZES, nearly zero energy schools; OCCuPANt, On the impacts of climate change on the indoor environmental and energy performance of buildings in Belgium during summer; PC, personal computer; PHS, passive house standard; PHPP, passive house planning package; PMP, platform masion passive (Belgium); Pixii, Onafhankelijk Kennisplatform Energieneutraal Bouwen (Belgium); QZEN, quasi zero energie; SHGC, solar heat gain coefficient; TABULA, building database typology in the European union; TMY, typical meteorological year; UK, United Kingdom; USA, United States of America; VAF, variable air flow; WWR, window to wall ratio; ZEBRA 2020, nearly zero-energy building strategy 2020.

* Corresponding author.

E-mail address: shady.attia@uliege.be (S. Attia).

\section{Introduction}

Energy use in the residential sector accounts for $20 \%$ of the total energy use at the European level [1]. The European Union (EU) states will cut carbon emissions to $55 \%$ of 1990 levels by 2030 [2]. To achieve the new carbon reduction targets, member states are required to increase their renovation rate from $2 \%$ a year to $3 \%$ annually before 2023 before stabilizing at least $2 \%$ in 2030 [3]. Conversely, existing households exceed the number of newly built households in Europe [4]. The existing building stock will continue to dominate for the next 30 years. In Belgium, the annual renovation rate of the existing building stock is less than 1\% [5]. As shown in Fig. 1, dwellings are responsible for 14\% of Belgium's greenhouse gas emissions. Awareness about the carbon emissions reduction potential of existing residential buildings is widespread among European governments, builders, housing associations, and building owners [6]. 


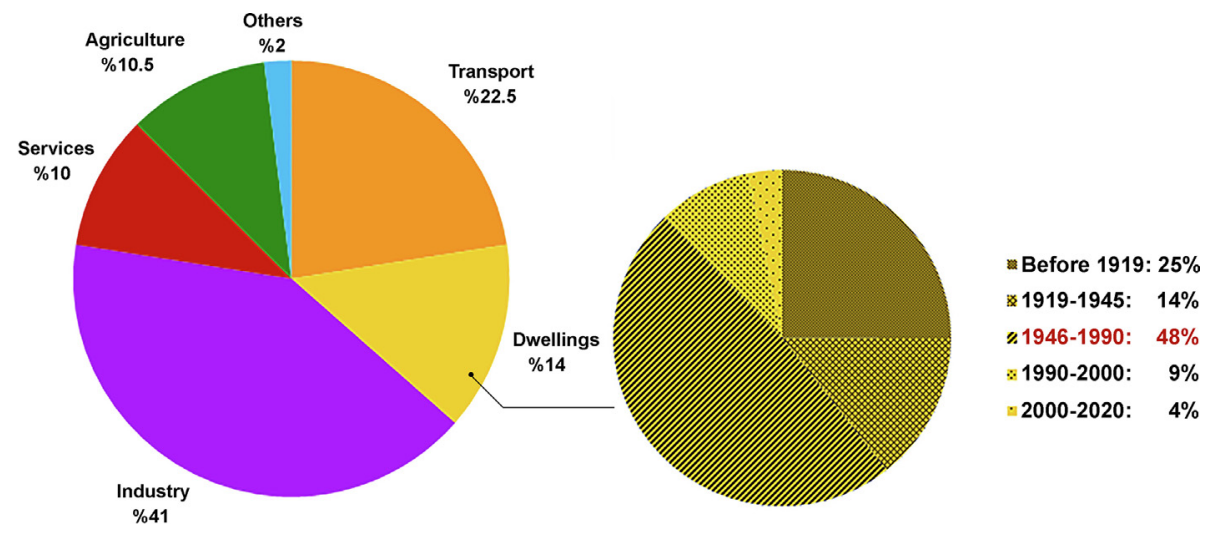

Fig. 1. Greenhouse gas emissions of Belgium in 2018 (\%) and the Distribution of Belgian dwellings by the period of construction [7,8].

While in North America and particularly the United States of America (USA), the benchmarking of existing buildings has acquired a consistent tradition $[9,10,11,12,13,14]$, in Europe this research is gaining more and more importance [15]. The TABULA [16] building typology project and the EPISCOPE [17] building monitoring projects are the most structured and central depository of building stock models. Since the Energy performance of buildings directive EPBD [18] came into force in 2003 and was implemented after 2008, member states across Europe had to develop 'reference building' representing their building stock [19]. According to the EU Commission Guidelines accompanying the Commission Delegated Regulation No. 244 (2012) [20], it is recommended that reference buildings are established representing the most typical building in a specific category (e.g., type of use and reference occupancy pattern or floor area or building envelope construction, etc.). However, in Belgium, the creation of representative benchmark models based on field measurements is still in its infancy. The OCCUPANt project [21], which developed two post-world war II (WWII) single-family reference models, characterized the energy use intensity of 1328 households $(n=1328)$. Among other results, more than $85 \%$ of occupants are older people, with an average age above 65 years old.

In this context, the selection of a building vintage and archetype are particularly crucial. In Belgium, Denmark, France, Germany, the Netherlands, Scandinavian countries, and the United Kingdom (UK), suburbanization after WWII encouraged the dwellers to live in single-family detached houses [22]. As shown in Fig. 2, postWWII single-family households often have gabled roofs and spacy plans. This large part of the building stock built after WWII did not comply with any energy efficiency requirements and was constructed inefficiently, even after the 1970s energy crisis. Today, post-WWII, traditionalist and baby-boom generations occupying those buildings reached their retirement age. However, the energy efficiency status of those buildings and their future remains unknown [23]. In Belgium, post-WWII households represent $48 \%$ of the existing building stock with an ownership rate exceeding $78 \%$ (see Fig. 1) [22]. Understanding the root causes of the performance gap across the post-WWII building stock improves the future renovation programs and increases their renovation potential.

Therefore, this study aims to accelerate post-WWII singlefamily houses' renovation by creating two validated benchmark models representing those buildings. Describing 633.702 households and characterizing their energy efficiency and their occupant behavior offers a valuable foundation. The aging of the existing occupants provides an opportunity to renovate those buildings with the ownership transfer. However, without accurate and granular data collected about single-family post WWII houses, renovation policies and strategies won't be effective [24]. The current study follows a cross-sectional study design where field surveys and auditing for more than 1320 households. The research directly engaged occupants who completed self-reported surveys and shared their energy bills compiled in a dataset about their buildings. The research methodology combines mixed research methods involving qualitative (e.g., literature review) and quantitative empirical and modeling (e.g., walkthrough audits, building performance simulation, calibration) research. Our study approach and methodology is similar to the work of Touchi et al. [25], Kragh, and Wittchen and Attia et al.[26,27] aiming to develop two simulation reference models based on monitoring and analyzing 1320 households. The building performance simulation models are implemented in EnergyPlus energy simulation program. A systematic and replicable approach for measurement and verficiation based on ASHRAE Guidline 14 was used to calibrate the building performance simulation models [28].

The study provides robust evidence of the extent of energy intensity use and the influence of occupant behavior of postWWII single-family housing in a temperate climate. The calibrated simulation models provide an operationally accurate virtual representation of buildings' energy performance. The calibrated models can allow to develope retrofit scenarios, calculate the potential energy-saving, and transform post-WWII buildings into energyneutral buildings [29]. At the same time, its methodology and findings can be useful across Western Europe. The relationship between occupancy profiles and energy use represents one of the most extensive national studies that characterize a remarkable residential building stock sector. The building energy models were created using a multizonal modeling approach distinguishing living areas, sleeping areas, and short presence spaces. On these bases, the paper presents a fundamental construct of two building energy models and their occupancy profiles that represent residential buildings to predict future renovation potential. Finally, the recommendations of future work renovation roadmap milestones that lead to an accelerated renovation rate are discussed.

\section{Methodology}

The research methodology is based on creating representative reference models for post-WWII detached single-family housing in Belgium. As shown in Fig. 3, the methodology implemented in this paper followed a hybrid approach involving empirical monitoring and modeling techniques. The literature review and field visits of more than a thousand dwellings allowed creating a database of WWII detached single-family housing. The analyses 


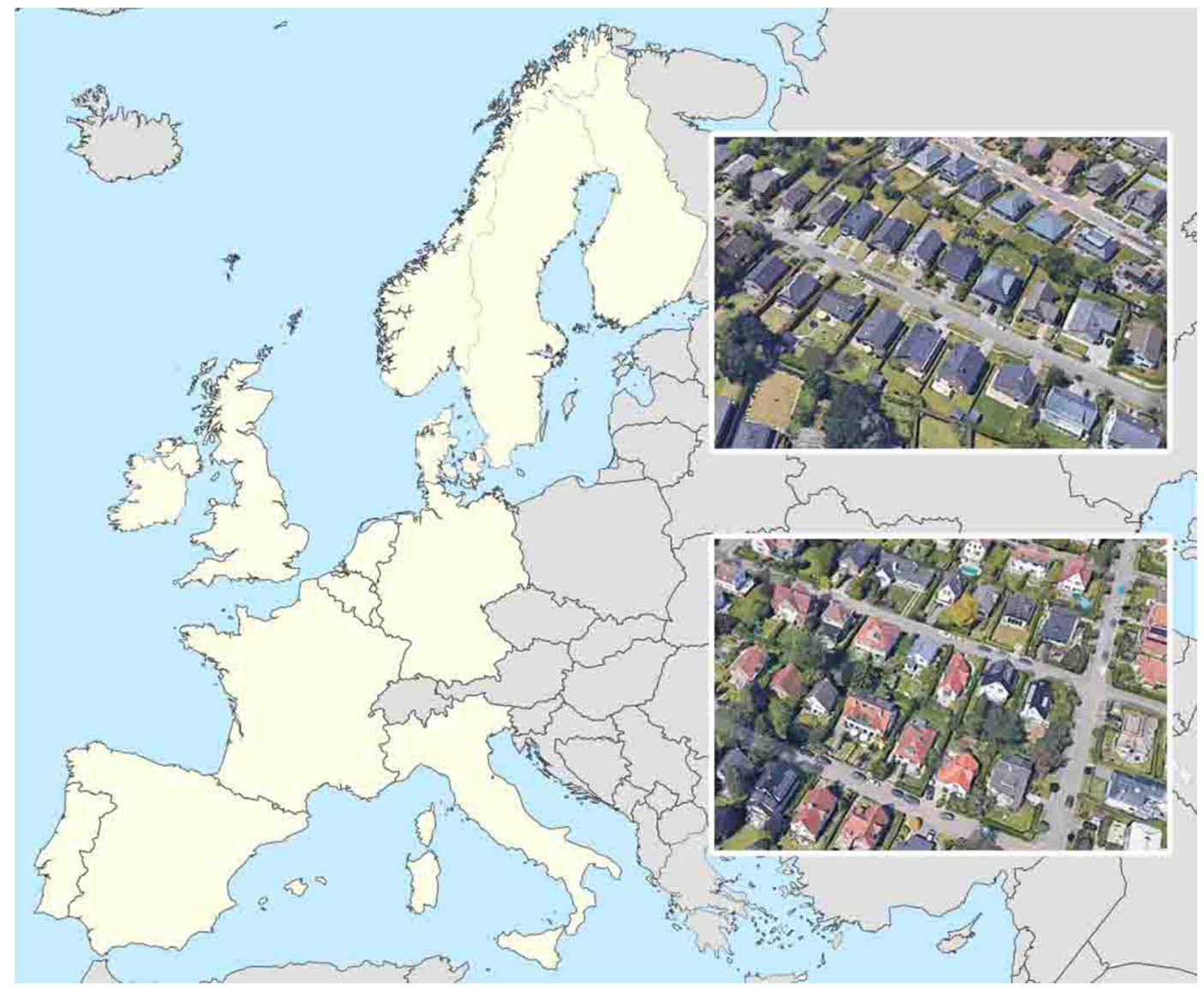

Fig. 2. Distribution of Belgian dwellings by period of construction.

allowed selecting two representative reference houses, determining their energy consumption, and characterizing their building performance systems and occupant's behavior. A full energy audit and four years of energy monitoring allowed generating highquality data. This data was then analyzed and used to create two building performance models. The model was calibrated and validated based on the monitored data. The methodology followed in this research is similar to other recent international energy modeling and benchmarking studies [26]. The methodology is similar to the approach of Tereci (2013) [30], who defined a reference building and calculated their energy use for different German archetypes; and Ghajarkhosravi (2020), who developed an energy benchmark models for multi-unit residential buildings (MURBs) in Toronto, Canada [31]. The following sections describe in detail the steps undertaken in this research.

\subsection{Literature review}

A literature review was conducted, including international publications that aimed to develop energy performance benchmarks for post-world war residential buildings. More than sixty publications were reviewed in the Belgian content concerning residential building benchmarking and energy efficiency characterization. The review included residential benchmarking reports that were developed as part of the EU cost-optimality approach for the three regions of Belgium; Brussels [32], Flanders [33], and Wallonia [34]. An exhaustive list of the reviewed studies and their content analysis can be found in this study's technical report [21]. Moreover, vital international studies on benchmarking were reviewed and summarized in the introduction. The review focused on state-of-the-art benchmark model creation approaches [19] and their calibration techniques for model validation [35]. The study also covered the most well-known building archetype databases, such as the US Department of Energy's archetypes database for residential buildings [13] and the European Projects TABULA EPISCOPE [17] that aim to provide reference buildings for the European building stock.

\subsection{Selection, mapping, and geolocalisation of post-WWII single- family houses}

A mapping study followed the literature review to select one of the most representative building archetypes in Belgium. The selection criteria of the archetype and construction vintage for benchmark model creation involved four main aspects. First, a high numerical representation of the selected archetypes for the existing building stock. Focusing on representative archetypes is a priority strategy for deep renovations [36] because it stimulates the standardization and cost reduction of renovation packages resulting in remarkable renovation increase [37]. Second, a low EPC rating of the chosen archetypes, based on elements including the building materials, its airtightness, and the building services installed. A poor EPC rating suggests low energy efficiency, which makes the renovation potential high [38]. Thirdly, an archetype with a geometry can allow for an external renovation without restrictions on appearance changes or being listed as monuments [39]. Fourth, owner-occupied single-family detached houses. Mixed ownership complicated the renovation decision, and private 


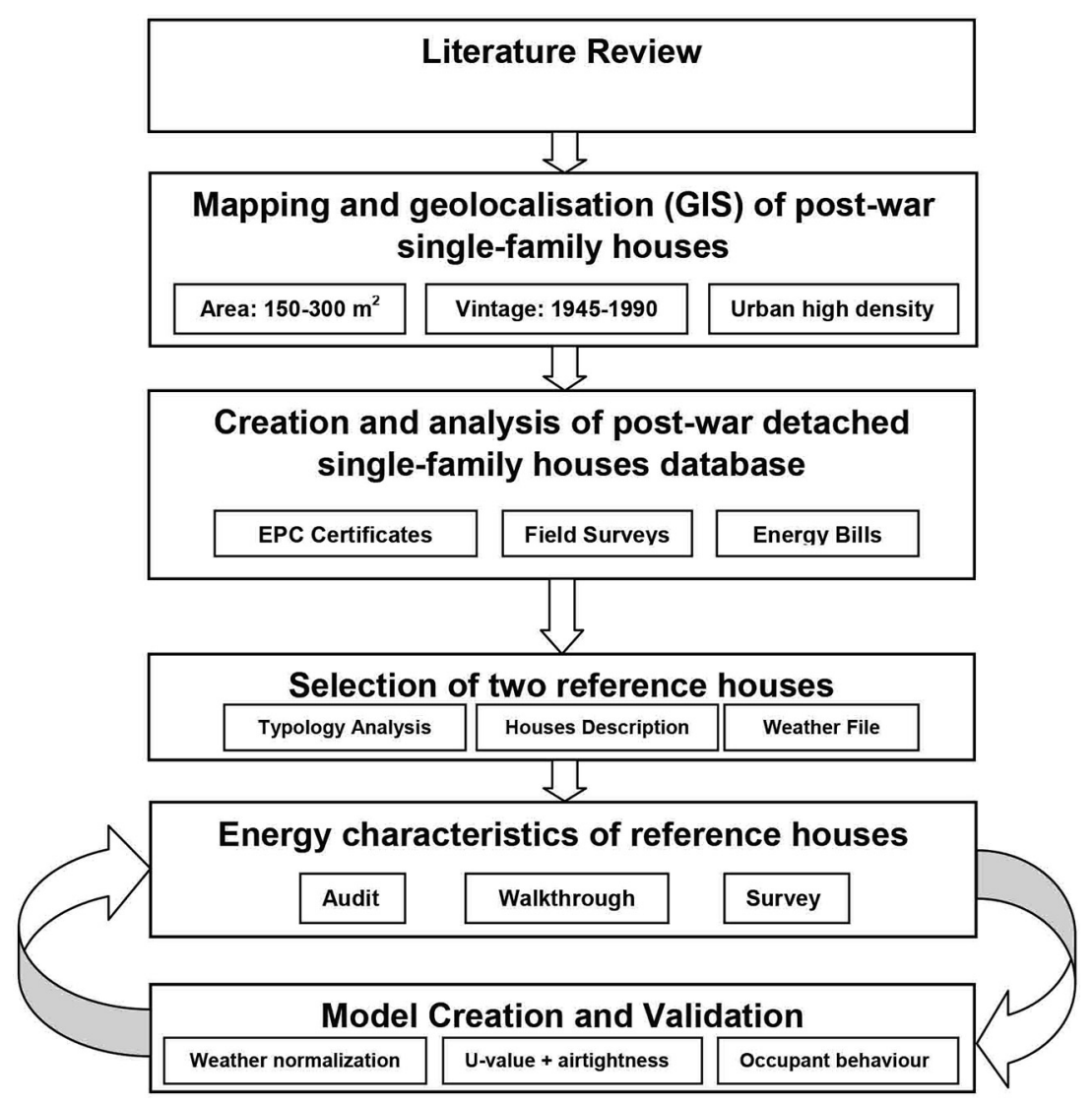

Fig. 3. Conceptual framework for the study methodology.

ownership allows easier access to renovation subsidies [40]. Thus, owner-occupied housing remains having a high potential for energy savings [41], and the ownership has a positive influence on the renovation decision [42].

As a consequence, post-WWII single-family detached houses were selected. Post-WWII single-family detached houses are generally speaking less homogenous than pre-war buildings [4]. In Belgium, most of those archetypes fall under the EPC label $F$ or G. They are fastly built using low-quality materials. They are poorly insulated at the time of construction. Therefore, they show a relatively high need for renovation.

Next, all existing detached residential buildings were mapped on the Belgian Cadastral Parcel Data (BCPD). The BCPD is a vectorial polygon map representing the cadastral parcels of the entire Belgian territory made available by the Land Registry Administration of Belgium [43]. The Geographical Information Systems (GIS) cadaster maps provide information about each building in Belgium, such as construction data, building use, number of floors, etc. [44]. Using construction date and building use, we extracted all residential buildings built before 1991 and after 1945 with an area $\geq$ of $55 \mathrm{~m}^{2}$ and $\leq 350 \mathrm{~m}^{2}$. We limited our mapping to detached single-family houses built before 1990 because energy efficiency regulations became only effective in Belgium in 1991.

Table 1

Distribution of single-family detached houses in Belgium.

\begin{tabular}{lll}
\hline & Num of buildings & Percentage \\
\hline Before 1945 & 245.070 & 27.89 \\
$\mathbf{1 9 4 5}-\mathbf{1 9 6 9}$ & $\mathbf{2 7 5 . 9 1 5}$ & $\mathbf{3 1 . 4 0}$ \\
$\mathbf{1 9 7 0}-1990$ & $\mathbf{3 5 7 . 7 8 7}$ & $\mathbf{4 0 . 7 1}$ \\
Total (before 1990) & 878.772 & 100
\end{tabular}

In terms of regulations, thermal insulation for new buildings was introduced in 1984 in the Walloon Region [45] and in 1992 in the Flemish Region [46]. The regulatory energy efficiency requirements applicable to new housing were only strengthened after the 1990s in the three regions (Flanders, Wallonia, and Brussels).

Table 1 list the portion of extracted buildings before 1945 and between 1945 and 1990. Table 1 demonstrates that most of the extracted buildings have been built between 1945 and 1990 (more than $70 \%$ ). Consequently, this study focuses on all residentialdetached buildings in Belgium constructed between 1945 and 1990.

The entire Belgium was divided into grids to conduct our field audits and surveys; each represents one ha $(100 \mathrm{mx} 100 \mathrm{~m})$. Each grid has been assigned a density index, which represents the number of buildings within the grid. Eighty-two grids distributed over Belgium were selected. They contain about 1500 buildings. Data were geo-processed with the help of a selection algorithm to rasterize and aggregate the vector data. The chosen sample represents $72 \%$ (633.702 households) of single-family detached houses built before 1991 in Belgium. According to [47], a sample size of 1000 can be considered an excellent representation of the study's phenomena. The developed mapping approach allowed identifying single-family detached houses grouped by hectare. The aim of identify the detached houses by hectare is to reduce the number of field visits and facilities the audits. Each selected hectare represents about fifteen houses, as shown in the results Section 3.1.

\subsection{Creation and analysis of post-WWII single-family houses database}

An initial database of 1500 households was created and updated based on the input from different regional databases 
(Brussels, Flanders, and Wallonia), field audits, and self-reported occupants' surveys. It included several details on each building such as the location, construction age, area, information on the architecture, type of materials, airtightness, heating system, ventilation system, renovation, occupancy, electrical appliances used, comfort in the home etc. The EPC databases in the three regions were consulted. Fortunately, the EPC details of all houses located in the Brussels Region were identified from the open-access Brussels Environment Database [48]. With the help of real estate websites, the EPC labels and EPB audits were retrieved for hundreds of houses. In this initial stage, this initial stage allowed us to compile the database and prepare for the following stage of field visits and audits.

Field visits were organized to visit the 82 ha representing the 1500 households between 2017 and 2021. All houses were visually inspected to assess the building envelope characteristics. The field surveys also enabled identifying and characterizing the energy systems (air and water heating systems, ventilation, lighting, smart meter, etc.) of individuals who could submit the survey by mail or online. Households' occupants were invited to sign a consent form to share their electricity and fuel bills (gas or fuel oil) via their energy providers. Once signed, it was possible to access their bills via the energy suppliers. Also, occupants were invited to fill in an online or paper survey that characterizes their building's energy efficiency. The consent form and survey content covered the building characteristics, domestic hot water, energy systems, and occupant behavior. Logbooks were also distributed to owners so that they could indicate their monthly consumption. In some dwellings, data loggers were installed to record consumption. Access to the forms and surveys can be found in the project report [21]. Finally, neighborhood organizations could also be contacted directly as it was often easier to convince people to communicate their bills through the local community.

Moreover, walkthrough audits were organized in more than 160 households voluntarily. Detailed energy audits involving blower door tests, u-value monitoring, energy system inspection, and occupancy behavior characterization were performed. Finally, the database was compiled, and missing information was completed to include 1050 households. The data collection process, analysis, and storage were done in line with the European Union General Data Protection Regulation, which was applied retrospectively [49].

\subsection{Selection of two representative reference houses}

A typology analysis took place for the 1328 houses to select two representative building configurations. The architectural and energy characteristics of the buildings have been analyzed concerning the building vintage. The analysis indicated a strong divide between the two vintages of post-WWII households.

First, (archetype A) detached houses built late 1940s throughout the 1969s had similar geometry, surface area, building materials, and occupant density. After WWII, it was necessary to house the population and rebuild the country. Under the federal law proposed by minister De Taeye, a new law allowed for the construction of 100,000 detached houses from its entry into force in 1954 [50] and reached 285,166 detached houses by 1969 . Taeye's law resulted from a compromise between two great movements: the socialist and catholic movements [51]. Taeye's law was the fruit of a campaign by Christian Democrats wishing to promote lowcost construction [52] of private dwellings outside the cities [53]. At that epoch, the Law of 1939 started to get implemented and made it mandatory to submit building permit applications accompanied by plans drawn up by an architect [54]. Consequently, many house owners resisted hiring an architect and opted to select identical house designs found in catalogs offered by architects for reduced fees. We interviewed several house owners from this epoch who confirmed this information. Contractors offered limited design alternatives of architectural designs against reduced costs for reproduction.

Consequently, typical De Taeye-archetype houses emerged with red bricks and ceramic roof tiles (see Result Section 3.2) [55]. Another point of similarity was construction materials. Singlefamily houses were constructed with inner walls of Ytong and were covered with external walls of traditional bricks [56]. Floors were built with lightweight concrete [57]. Other influential factors that lead to grouping single-family houses built between 1945 and 1969 under one archetype to represent a vintage were demographics and household surface area. Our field studies revealed that houses built before 1970 exceeded the $200 \mathrm{~m}^{2}$ area threshold and homeowners had an average of three to four children per household. Between 1945 and 1969, birth rates boomed in Belgium [58]. On the opposite, households built between 1970 and 1990 were less than $200 \mathrm{~m}^{2}$ and witnessed a decline in birth rate per household, reaching on average two children.

Second, (archetype B) detached houses built between the 1970s throughout 1990s had similar geometry, surface area, building materials, and occupant density. Despite this archetype's geometrical similarity, the facades and envelope cladding became more heterogeneous [59]. There has been an evolution in lightweight concrete for walls, from infills principally to loadbearing walls [56]. A proliferation of insulation materials and systems occurred. Norms and regulations evolved, and the BBRI published several technical reports on the insulation of flat roofs. The BBRI promoted construction standards and published the 'General specifications for the execution of private buildings,' co-edited with the Royal Federation of Architects' Associations in Belgium (FAB) and the National Confederation of the Building Industry (NCB) [56]. Despite the emergence of the oil crisis in the 1970s, there was no systematic improvement in building energy efficiency. However, the occupied areas were remarkably reduced. The single floor bungalow archetypes with I or L plans dominated the single-family households' construction scene.

Finally, the two representative buildings were also selected strategically. Plans and geometric forms of the two houses were described and analyzed. Based on the typology analysis and classification, two theoretical reference models were created. The energy performance data compiled in the database (Section 2.3) allowed us to select two typical archetypes to represent the 1945-1969 and 1970-1990 vintages.

\subsection{Energy characteristics of reference houses}

Two levels of energy characterization are carried out for the selected houses based on the recommendations of Krarti [60]. An analysis of energy use intensity (electricity and natural gas) and a walkthrough survey are conducted between 2016 and 2019 for 1500 households. Key informant interviews are conducted in Dutch and French one-to-one with main stakeholders living in the selected hectares with first-hand knowledge of the location. The key informal interviews assured introducing the project, building trust, and maintaining confidentiality. The walkthrough surveys allowed us to inspect the energy efficiency characteristics and energy use for 2016-2019 based on monthly bills. The walkthrough audits allowed us to understand the performance of the building and to identify the usage patterns. Monthly energy use was retrieved via private databases. Private companies such as Engie, Lampiris, and Luminus gave access to the consumption data 
based on the occupant's consent. The Commission de Régulation de l'Electricité et du Gaz (CREG) database was also used as part of the study. The CREG is the federal organism for the regulation of the electricity and natural gas markets in Belgium. This allows consumers to compare their current energy contract with the current market offer. It collects data on the production and consumption of electricity and gas in Belgium and reports on price trends. As a result of this step, 250 households were excluded from the 1500 households sample due to data discrepancies or none constituent consent. As a consequence, 1328 audits were conducted via field visits and self-administered online and paper-based surveys.

The second type of energy characterization was highly detailed and involved several techniques to reduce the uncertainty of energy efficiency characterization parameters and occupancy patterns. The smartphone-based survey was developed to identify the occupancy density and profiles in the different households' thermal zones on a daily, weekly, monthly and seasonal level. With some modifications made to meet the current occupancy profiling exercise's objectives, the survey was replicated at the building level for representative samples of archetypes A and B. The sampling design consisted of a random sample-a free, open-source application allowed collecting the responses and compiling them on the server via the cloud. Once repetition of the answers patterns was found, the request of occupancy information input was stopped.

As a consequence, 160 household occupants participated in the occupancy surveys between 2016 and 2019. The collected data was compiled with the central project database and analyzed to describe the representative households' energy performance to serve later the building modeling stage. The occupancy surveys provided insights to justify the choice of the two representative archetypes.

The annual occupancy schedule has been set based on an average yearly schedule representing 2016-2019. The occupancy surveys and data loggers' data were used to determine households' heated thermal zones, size, composition, age, and occupants' presence. The survey involved information about water consumption and Domestic Hot Water (DHW) use. The number of vacation days was determined per household. The daily occupancy schedule has been established in line with ISO 18,523 recommendations [61]. A special section in the energy audit involved characterizing the artificial lighting, HVAC systems, and energy sources. The audit questionnaire included questions describing the mechanical ventilation systems and components. Mobile heating units and heating were checked. Visual inspection for all chimneys took place to trace and understand the heating strategy and energy sources.

\subsection{Development of the benchmark models}

Two representative simulation models were made based on the previously described selection process and building characterization. The building energy models were created using EnergyPlus (Version 8.2.0) [62].). All simulations were performed for the location of Uccle, in the Brussels-capital region, in Belgium. The country falls almost entirely within Köppen-Geiger classification of temperate oceanic climate $(\mathrm{Cfb})$ with no dry season and warm summer [63]. Overall, Belgium's climate is mild-cold and humid, with a significant amount of rainfall during the year. Residential buildings are typically heating-dominated with an average of 2941 Heating Degree Days (HDD) and 90 Cooling Degree Days (2014-2019, base temperature $15^{\circ} \mathrm{C}$ HDD and $24{ }^{\circ} \mathrm{C}$ CDD) [64]. Brussels meteorological weather data for
2016-2019 were requested from the Belgian Royal Meteorological Institute [65].

\subsubsection{Calibration}

The building energy models' validity has been further checked against the public statistics and verified through a model calibration and utility bill comparison. According to ASHRAE Guideline 14 [58], calibration was done to evaluate the goodness-of-fit of the energy models. The ASHRAE Guideline 14 uses two indices to assess the goodness-of-fit of the building energy model [66]. The Mean bias error, MBE, and the Coefficient of variation of the Root mean square error, CV (RMSE). MBE is a nondimensional measure of the overall bias error between the measured and simulated data in a known time resolution, and it is usually expressed as a percentage:

$M B E=\frac{\sum_{i=1}^{N p}\left(m_{i}-s_{i}\right)}{\sum_{i=1}^{N p}\left(m_{i}\right)}[\%]$

where $\mathrm{mi}(\mathrm{i}=1,2, \ldots, \mathrm{Np})$ are the measured data, si $(\mathrm{i}=1,2, \ldots, \mathrm{Np})$ are the simulated data at time interval $\mathrm{i}$ and $\mathrm{Np}$ is the total number of the data values.

$\mathrm{CV}$ (RMSE) represents how well the simulation model describes the variability in the measured data. It is defined as:

$C V(R M S E)=\frac{1}{m} \frac{\sum_{i=1}^{N p}\left(m_{i}-s_{i}\right)^{2}}{N p}[\%]$

where, besides the quantities already introduced in Eq. (1), $\mathrm{m}$ is the average of the measured data values. The evaluation of a building energy simulation model's accuracy is made according to the model's conformity with the recommended criteria for MBE and CV (RMSE).

According to the ASHRAE Guideline 14, the simulation model is considered calibrated if it has MBE that is not larger than $5 \%$. CV (RMSE) is not larger than $15 \%$ when the monthly data are used for the calibration.

To get reliable building energy models and increase the accuracy of estimating the building's performance, the models of detached single-family houses underwent two subsequent calibrations. The building model was first calibrated based on the building's measured monthly gas consumption. An uncertainty analysis was then performed to identify the most influential independent input variables, including the weather, building envelope, and occupancy [67].

\subsubsection{Weather normalization}

Weather normalization was applied to isolate weather changes on the archetypes energy performance for the period 2016-2019 [68]. The degree-days method was used to represent the total positive or negative difference [69]. The degree day is the difference between a base temperature and an average temperature of the place taken as a reference. This notion considers that the heat losses are proportional to the difference between the indoor $\mathrm{T}^{\circ}$ and the outdoor $\mathrm{T}^{\circ}$ of modeled building. This degree-days method, therefore, allow to establish the normalized consumption. The relationship between these two consumptions can be selected based on the equation below:

Normalized consumption $=\frac{\text { monitored energy use } \times \text { normal degree days onsite }}{\text { observed degree days onsite }}$

\subsubsection{Building envelope performance monitoring}

The envelope airtightness and conductivity values were identified as influential modeling input parameters with high 
uncertainty. Despite the airtightness values found in several studies [70], including the earliest work of Bossaer et al. (1998) [71], we could not find a reliable value of envelope infiltration at $50 \mathrm{~Pa}\left[\mathrm{~m}^{3} / \mathrm{h} . \mathrm{m}^{2}\right]$ for the detached houses built between 1945 and 1990. Therefore, an airtightness test took place using the pressure measuring device DG-700 and software TECTITE Express 5.1 and BlowerDoor $^{\circledR}$ measurement according to EN 13829 [72] and STS P 71-3 [73].

Moreover, a 21 days U-value monitoring took place on different envelope surfaces using gSKIN ${ }^{\circledR}$ KIT-2615C (U-Value Kit) according to ISO 9869-1:2014 [74]. The kits were installed to measure a representative brick cavity wall [75], the roof, and the attic (loft) floor. Most of the investigated attic slabs were insulated, and literature [16] did not provide accurate and representative values. Therefore, the conductivity and heat capacity of the attic slab required special attention.

\subsubsection{Occupancy behavior verification}

With the house owners' consent, three data loggers, namely TESTO IAQ 160, were placed in the two selected houses. The data loggers uploaded five readings (temperature, humidity, $\mathrm{CO} 2$, and pressure) every 15-minutes to the cloud. The field measurements took place in the summers of 2018 and 2019 to refine residents' specific behavioral characteristics. With the help of the survey responses and the monitoring data, occupancy schedules were verified. Lighting, plug loads, and domestic hot water schedules were developed based on the energy and indoor environment monitoring data. The profiles were accordingly scaled to match the needs of the building energy modeling software based on the work of Koupaei et al. 2019 [76]. After defining both daily and yearly periods of heating (and cooling), and natural ventilation using meteorological weather, the heating, cooling, and natural ventilation schedules were created.

\section{Results}

The results of the database are presented in this section. The two selected reference buildings are described in detail regarding their energy characteristics, energy models, and the validation results.

\subsection{Database of Belgian post-WWII single-family houses}

The buildings are grouped according to their archetype and organized by hectare. Fig. 4a shows the Distribution of extracted buildings per municipality in Belgium. Fig. 4b indicates that most detached residential buildings are concentrated in the northern and middle parts of Belgium. Accordingly, our selected grids contain 1500 buildings located within the north and middle of Belgium (Fig. 2) to ensure well representation of extracted buildings.

However, a comprehensive database of 1328 households was created, bringing together all the post-WWII single-family houses database's geometric and energy efficiency characteristics. The architecture of the one thousand houses was analyzed. Two archetypes of houses were identified from the data collected: archetype A corresponding to dwellings built between 1945 and 1969 and archetype B corresponding to homes constructed between 1970 and 1990. Both archetypes had to be distinguished due to the disparity in architecture, house configuration, occupancy density, and energy performance. Fig. 5 represents the one thousand reference dwellings visited during the field surveys for typology A and B.

As shown in Fig. 5, the architectural style and the vintage and other characteristics such as the occupant density and construction materials differ between these two periods. Archetype A (19451969) included 716 audited households. The measured energy use (electricity and natural gas) for archetype A in 2018 is presented in Fig. 6. The measured energy use (electricity and natural gas) for archetype A in 2018 is presented in Fig. 6. Archetype B (1970-1990) included 612 audited households, and its measured energy use breakdown is presented in Fig. 6.

\subsection{Selected reference buildings}

Two reference buildings were identified as a representative, as shown in Fig. 7 and described in Table 2. Archetype A represents the 1950 s and 1960s free-standing housing. First, archetype A represents a standardized rectangular plan with a cavity wall cladding with brick. The typical house comprises two floors with unoccupied attics and is covered with a sharply gabled roof. Most of the households had an underground garage and a cave. The archetype came within reach of broad sections of the Belgian population from the 1950s onwards [77] and was named the 'Belgian Villa,' or the

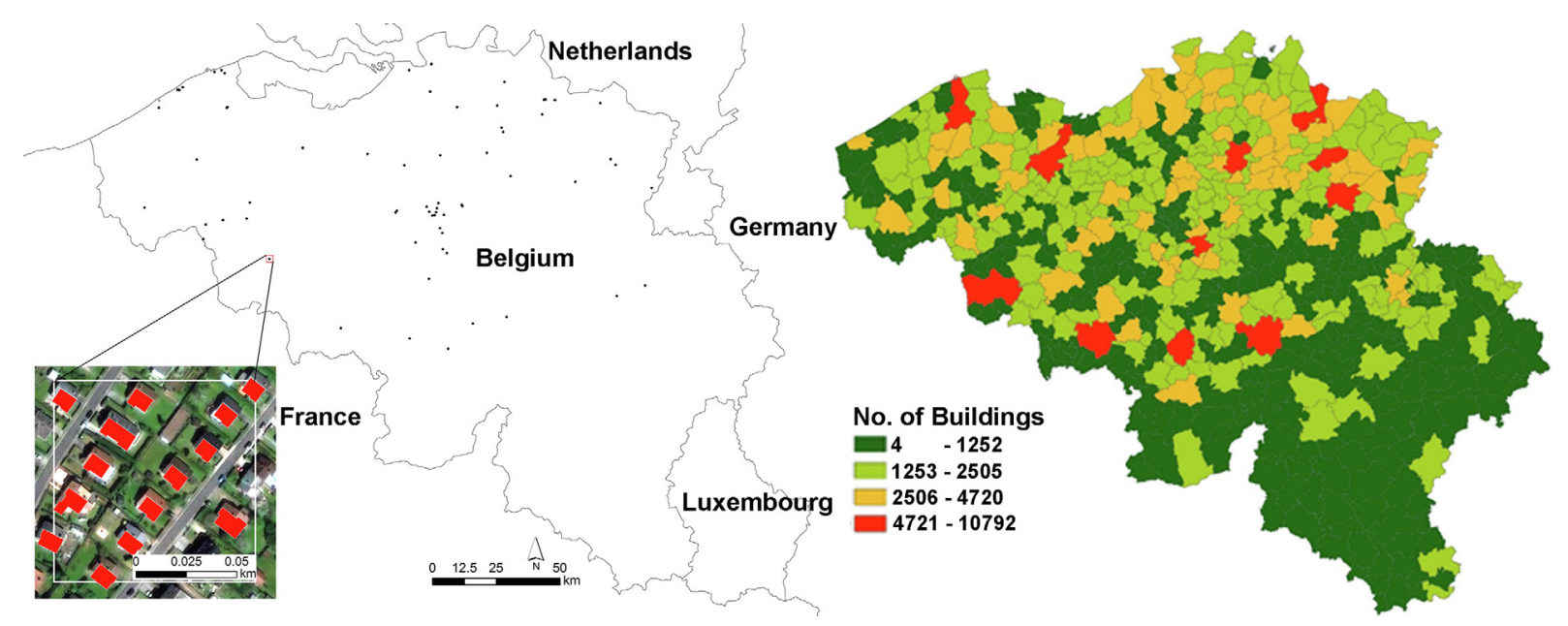

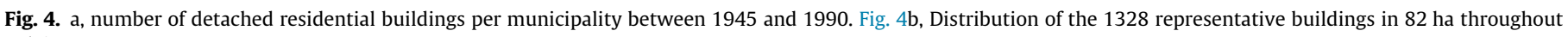
Belgium, 


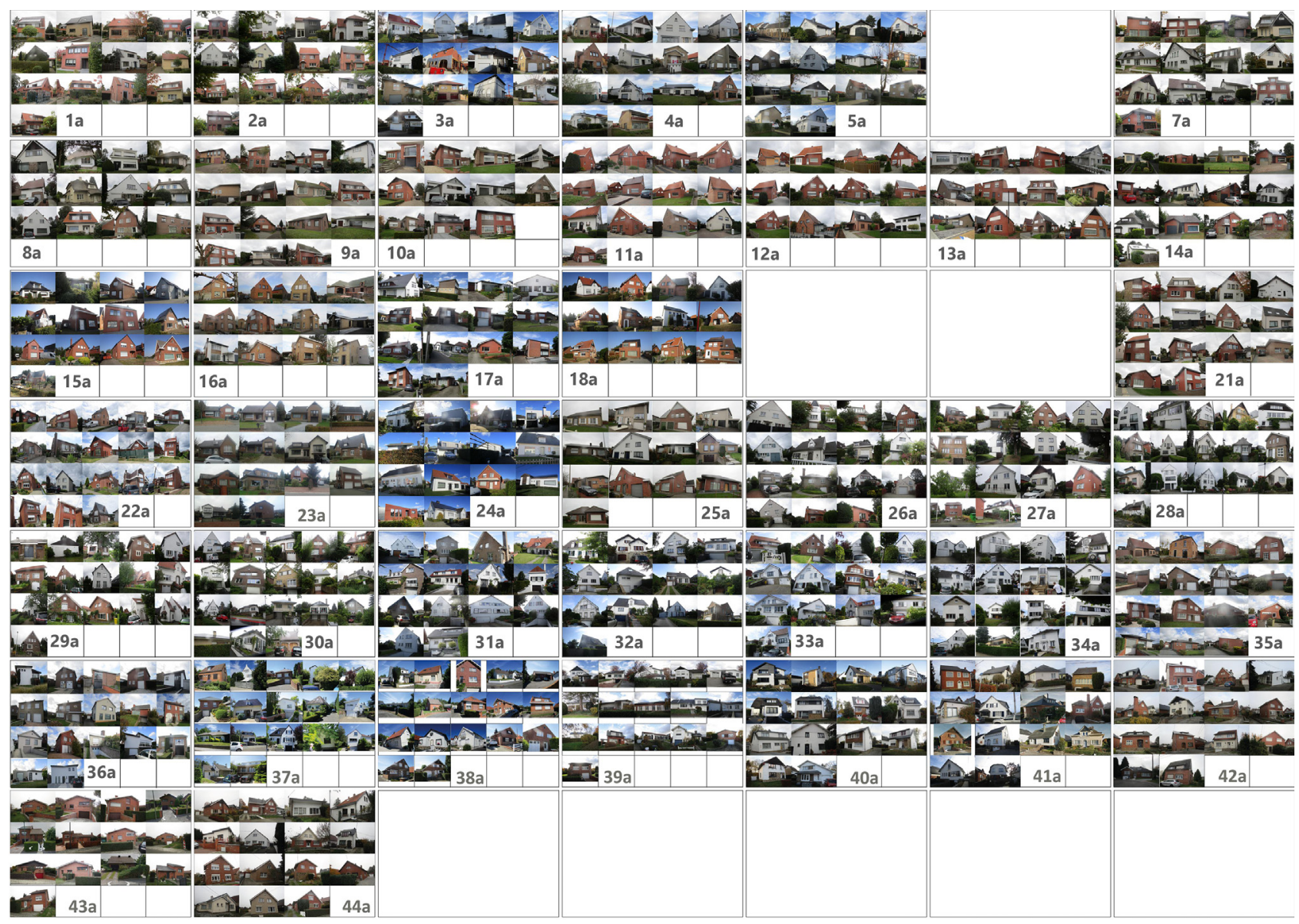

Fig. 5. a. Dwellings representative of archetype A, Fig. 5b. Dwellings representative of archetype B.

'Fermette' or 'De Taeye-houses' [78]. The average surface area is often between $250 \mathrm{~m}^{2}$ and $300 \mathrm{~m}^{2}$. The houses historically comprised at least two chimneys and were heated with fuel oil. From the audited sample (716 homes) we found that more the $70 \%$ of households went through an energy retrofit and replaced the fuel oil with natural gas boilers.

Second, archetype B is characterized as a single-floor house, unoccupied attic, and a separate garage unit next to the house. Archetype B represents standardized rectangular or L-shaped plans with a cavity wall, which is cladded with brick. Fig. 7 shows the selected reference building. The archetype gained importance in Belgian living culture in suburbia. It represented the rural and rustic style of pseudo farm housing [79]. Facades comprised of retroelements and washed old brick (cavity walls) [78]. The house plan was more open, avoiding a reception space with an open kitchen. The average surface area is often between $180 \mathrm{~m}^{2}$ and $240 \mathrm{~m}^{2}$. The archetype was named the 'Bungalow' with prefabricated concrete attic floors and ground slabs [78]. The attic side walls had a typical timber cladding, and the houses seemed to be more standardized and fabricated in an industrial way.

The building energy models are multizonal thermal spaces that are categorized as (1) living area (living, dining, and kitchen), (2) sleeping area (bedrooms), and (3) short-presence area (bathrooms and corridors. Fig. 8 illustrates the two modeled archetypes in 3D view. Fig. A1, in Appendix I, shows the plans and facades of both archetypes. Further details regarding the thermal zoning schemes can be found in a detailed modeling report [21].

\subsection{Energy characterization of the two reference buildings}

The energy characteristics of the two reference simulation models are described in this section.

\subsubsection{Energy use intensity}

As shown in Fig. 7, the EPC rating of archetype A is F, and the rating of archetype $B$ is $E$. The carbon emissions calculations are based on the assumptions proposed by Georges et al. [80]. The characterization of the energy use of the 1328 households indicated that the average energy use intensity of archetype $A$ is $148.7 \mathrm{kWh} / \mathrm{m}^{2} /$ year for heating (including DHW) and $17.7 \mathrm{kWh} /$ $\mathrm{m}^{2} /$ year for electricity. Fig. 7 indicates that archetype B's average energy use intensity is $139.8 \mathrm{kWh} / \mathrm{m}^{2} /$ year for heating (including DHW) and $14.9 \mathrm{kWh} / \mathrm{m}^{2} /$ year for electricity (see Table 3 ).

\subsubsection{Occupancy density and schedules}

Archetype A was dominated by senior couples or single female seniors (>70 years old). Almost all of the investigated occupants were first house owners. In the past, they had, on average, three children who all left the house. A significant amount of survey respondents indicated a usufrucuary ownership, which means they do not have full ownership of the property right. Most interviewed occupants granted the usufruct to their children or grandchildren to reduce the inheritance tax burden. Archetype B was dominated 


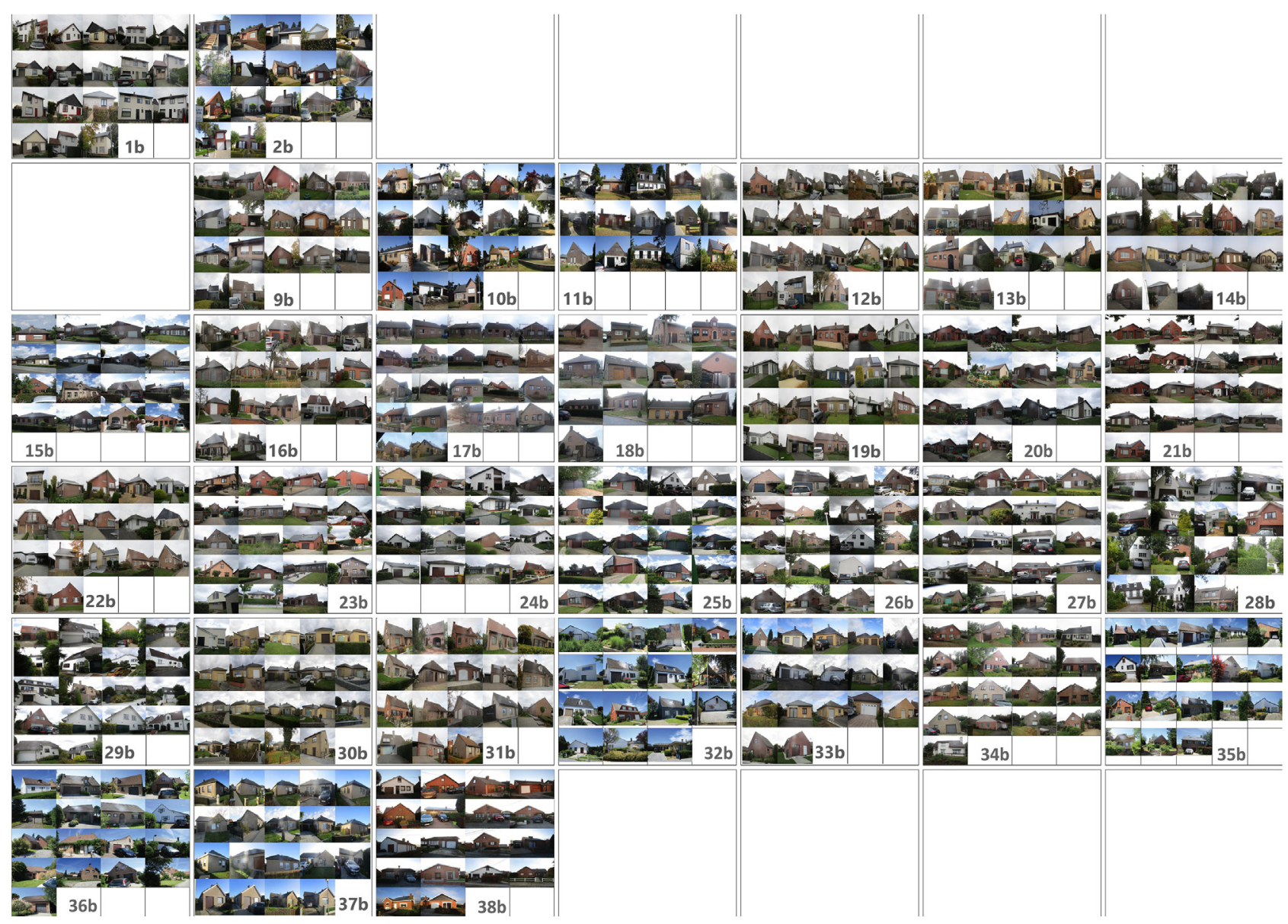

Fig. 5 (continued)

by senior couples ( $>60$ years old) where at least one occupant was pensioned. Overall the occupancy density in both archetypes was low, and several spaces were not used.

Based on the schedule available in the standard ISO 18523 part 2, we defined the occupancy period. However, ISO 18523 was developed for an average age category of 45-year old occupants. Therefore, our surveys and monitoring observations were used to create novel schedules. Fig. 9 presents the occupancy schedules for the three space categories as (1) living area (living, dining, and kitchen), (2) sleeping area (bedrooms), and (3) shortpresence area (bathrooms and corridors. Since occupants were mainly seniors, we considered the same schedules for a weekday and the weekend. Tables 4 and 5 summarize the holidays and occupation periods use for both archetypes.

\subsubsection{Lighting intensity and schedules}

The data collected from the survey allowed us to define the most commonly used types and numbers of lamps. The dominant types of lamps used were mainly compact fluorescent lamps (64\%) followed by LED lamps (28\%). Halogen lamps were found primarily in the dining and living areas. Artificial lighting was not used during the daytime of the day or in the absence of occupants. As seen from the survey, the average lighting power intensity for living areas was $12 \mathrm{~W} / \mathrm{m}^{2}$. For the bedroom, for example, the average lighting power density is $8 \mathrm{~W} / \mathrm{m}^{2}$, with an average variance of $6.1 \mathrm{~W} / \mathrm{m}^{2}$. Fig. 9 presents the lighting schedules applied to the three main space categories. Lighting schedules were modified during the winter period to extend the operation in the living areas
$2 \mathrm{~h}$ after 08:00 and $1 \mathrm{~h}$ before 17:00. Several attempts to validate the lighting schedules were achieved by comparing the outcomes with the reports published by Flemish Energy Agency [81] and IP Belgium [82].

\subsubsection{Plug load intensity and schedules}

The penetration rates and saturation rates of house appliances were determined based on survey findings. Table 6 lists the most found house appliances in Belgian post-WWII single-family houses. The 20 listed appliances had a saturation rate higher than $65 \%$ in the surveyed sample. The national average of household appliances is 77appliance per household [83]. The unit capacity of the plugged appliances (standby and continuous) was estimated based on the running hours and power values. The average plug load power intensity is estimated at $9 \mathrm{~W} / \mathrm{m}^{2}$. Surprisingly, around $15 \%$ of households had an air conditioning unit (split), $17 \%$ had a dehumidification device, and $25 \%$ had mobile electric heating devices. Finally, the monthly and annual electricity use was used to validate the modeling assumptions.

\subsubsection{Cooking and domestic hot water}

Most visited households were connected to the district gas grid. Households located in Walloon and Flemish Brabant, Hainaut, Brussels, and Antwerp provinces were mostly using lean gas imported from the Netherlands. The households are in a transition phase since 2018 and until 2029 to replace it with rich gas. Lean gas will be replaced by rich gas imported from Norway, the United Kingdom, Qatar, and Russia. Most households had gas-fired boilers 

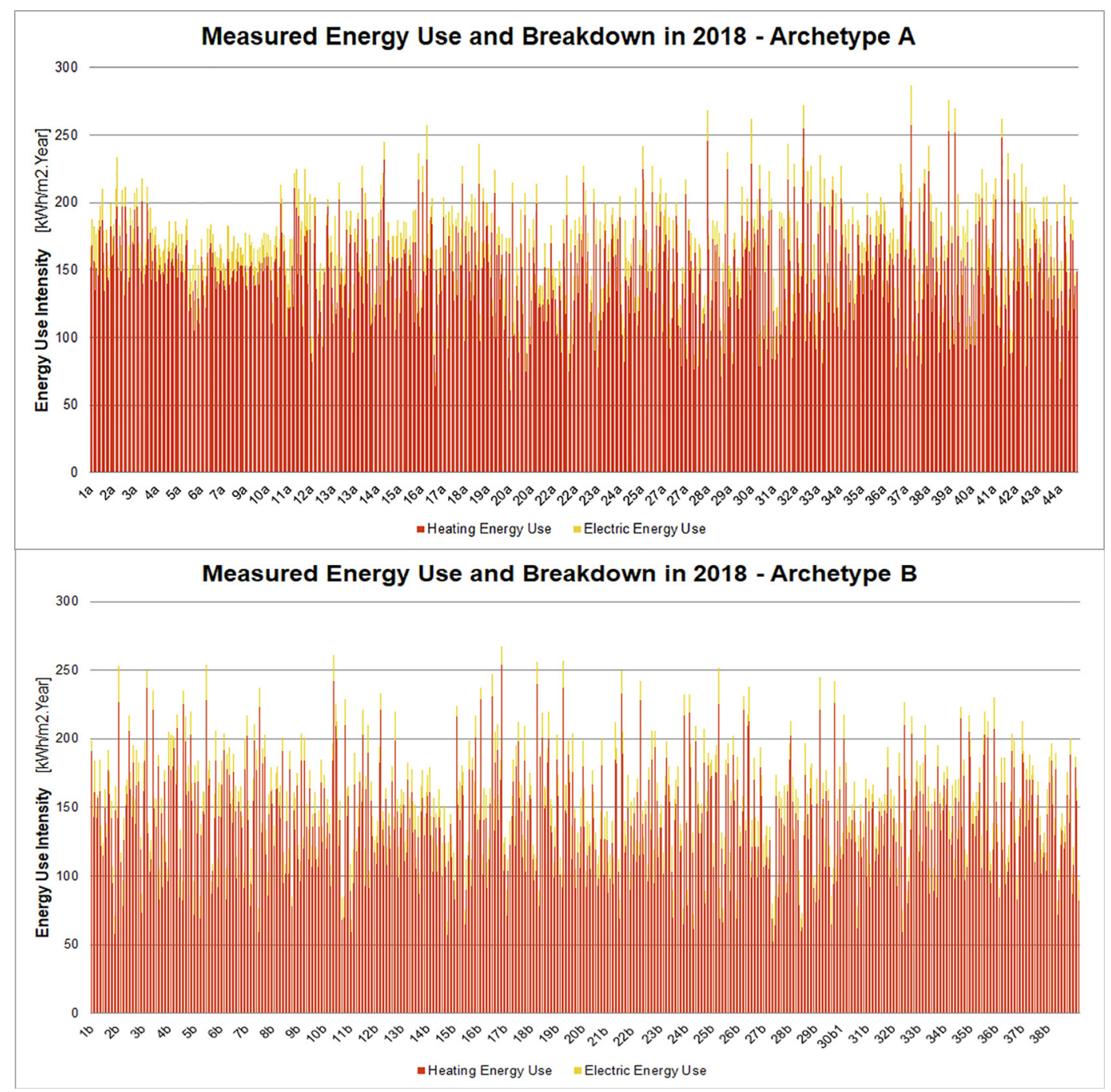

Fig. 6. a. Measured energy use intensity for archetype A, Fig.6b. measured energy use intensity of archetype B.

that were replaced after 1990 and thus are compatible with rich gas. The analysis of gas utility bills allowed defining the baseline of energy use for DHW and cooking (see Section 3.3). The water use per person was surveyed, representing an average of $30 \mathrm{~m}^{3}$ per household (2 senior occupants), which stands for $41 \mathrm{~L} /$ person/day. The DHW hot water (of $60^{\circ} \mathrm{C}$ ) was calculated to reach $25 \mathrm{~L} /$ person/day. The cooking activities were assumed to reach 4060 min per day.

\subsubsection{HVAC systems and comfort setpoints}

More than $80 \%$ of households were heated by natural gas. A small number of households had a fuel oil boiler or a pellet or wood logs heating system. More than $90 \%$ of households had a hydronic heating system with a hot water loop and radiators. The household owner indicated replacing the heating system at least once before the year 2000. Radiators were fitted with thermostatic valves to control hot water flow in response to the local sensed setpoint temperature. Radiators in children's rooms and non-occupied spaces were left closed. The thermostat average setpoint temperature was $23{ }^{\circ} \mathrm{C}$ in living areas, including the kitchen. Radiators were completely open. The thermostat in the bathroom and short-presence areas were set to $16{ }^{\circ} \mathrm{C}$ where radiators were left closed. Occupied bedrooms were set to $18^{\circ} \mathrm{C}$, where radiators were left half-open. The real measured setback temperature in both households was $13{ }^{\circ} \mathrm{C}$ when occupants were absent during holidays. Therefore, the thermal comfort setpoint criteria complied with ISO 17772-1,2 requirements (Category I) [84] for senior adults with low metabolic rate and impaired control of body temperature [63] and [64]. Almost none of the investigated households had a mechanical ventilation system. $78 \%$ of survey respondents indicated opening windows for natural ventilation during winter and summer. Several attempts to validate the heating energy use and schedules were achieved by comparing the outcomes with the reports published by the Flemish [86] and Walloon [87] and federal government [88].

\subsection{Numerical model calibration}

Several iteration rounds tool place based on several input validation measures. The MBE and CV(RMSE) values of monthly energy use were calculated and are presented in Table 7. The obtained values are in acceptable ranges

Table 8 indicates the energy use intensity normalization after weather normalization. Brussels' HDD days were extracted from the Eurostat website for the years 2016-2019 [64]. Both archetypes' energy use was compared with the observed energy use 


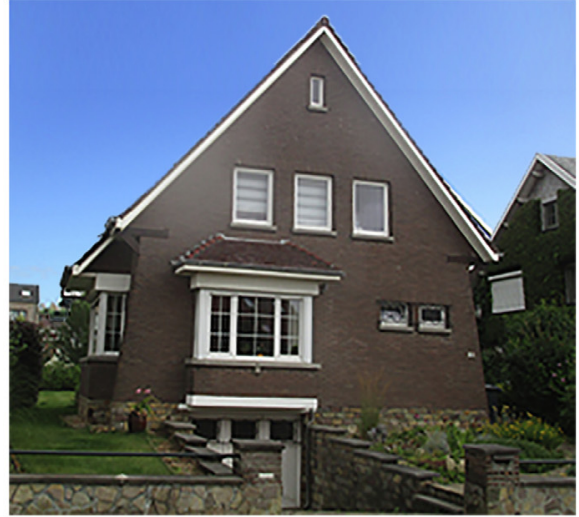

Archetype A

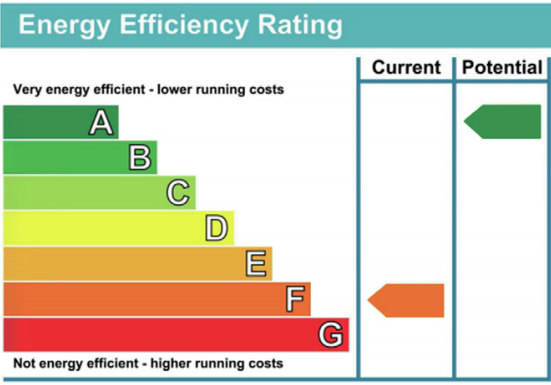

Gas boiler

Single glazing

No ground/roof insulation

EUI: $166 \mathrm{kWh} / \mathrm{m}^{2} /$ year

Carbon: $32 \mathrm{~kg} \mathrm{CO} / \mathrm{m}^{2} /$ year

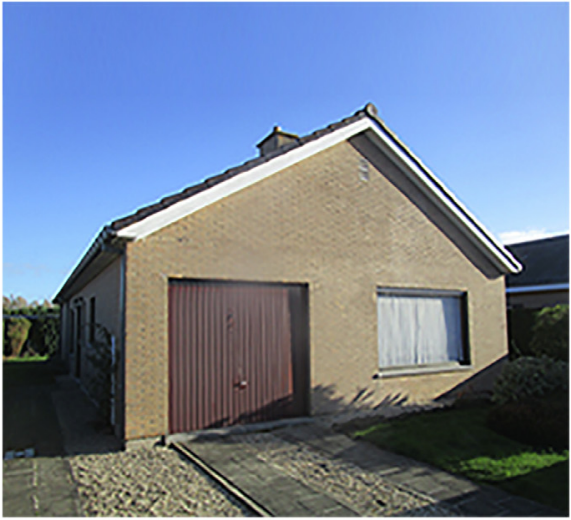

Archetype B

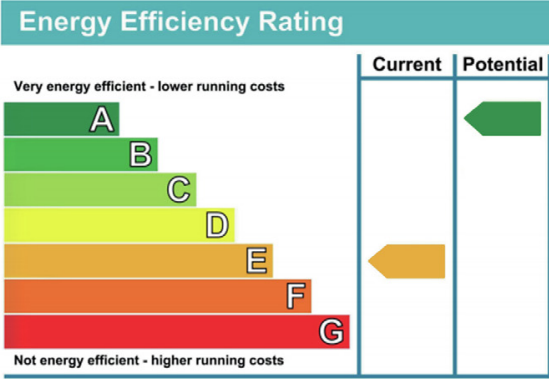

Gas boiler

Double glazing

No ground/roof insulation

EUI: $155 \mathrm{kWh} / \mathrm{m}^{2} /$ year

Carbon: $33 \mathrm{~kg} \mathrm{CO} / \mathrm{m}^{2} /$ year

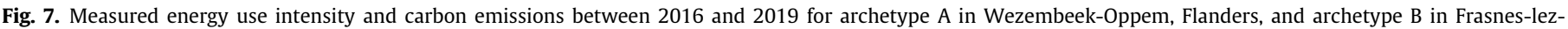
Anvaing, Wallonia.

Table 2

General description of archetypes A and B.

\begin{tabular}{lll}
\hline Building description & Archetype A & Archetype B \\
\hline Number of floors & 2 & 1 \\
Total area $\left(\mathrm{m}^{2}\right)$ & 259 & 148 \\
Occupants & 2 & 2 \\
Total volume $\left(\mathrm{m}^{3}\right)$ & 774 & 636 \\
External wall area & 254 & 198 \\
Roof area & 192 & 187 \\
Floor area & 259 & 148 \\
Windows area & 24.7 & 20.4 \\
Windows U-value & 2.90 & 2.76 \\
Windows G-value & 0.74 & 0.60 \\
Wall surface absorptance & 0,80 & 0.70 \\
Walls U-value $\left(\mathrm{W} / \mathrm{m}^{2} \mathrm{~K}\right)$ & 1.72 & 1.70 \\
Roof U-value $\left(\mathrm{W} / \mathrm{m}^{2} \mathrm{~K}\right)$ & 1,25 & 1.40 \\
Ground U-value $\left(\mathrm{W} / \mathrm{m}^{2} \mathrm{~K}\right)$ & 0.46 & 0.46 \\
Attic Floor $\mathrm{U}$-value $\left(\mathrm{W} / \mathrm{m}^{2} \mathrm{~K}\right)$ & 1,1 & 1.1 \\
\hline
\end{tabular}

intensity extracted from the energy bills. The difference between the heating degree values lies between $-4^{\circ}$ and $+3.5^{\circ}$ HDD-the weather normalization allowed to neutralize the effect of weather and validate the results presented in Table 3.
Moreover, the envelope input parameters were refined through $\mathrm{U}$-value monitoring and airtightness measurements. The final Uvalues of the building envelope and internal floors are presented in Table 9. Also, the blower door test results are indicated in Table 9. The leaky nature of the households was confirmed due to the difficulty to reach 50 Pascal when depressurizing the tested buildings. Several plastic masks were taped over electricity outlets, chimney dampers, opening frames until we could calculate the total air change per hour from air leakage with an accuracy of $90 \%$.Our findings are close to the assumptions reported by the Flemish [50] and Walloon [67] studies. More important than the absolute energy use per household, it was essential to provide reliable envelope performance values based on in-situ monitoring. The reported values reduced the uncertainty of the building energy model remarkably.

In a final attempt to validate the multizonal energy model, household occupancy profiles were refined. The repetition of the surveys allowed us to reach a high agreement on the most probable profiles. Despite the size of the large dwellings, the occupancy characterization confirmed that the elderly occupied both households. However, the most important observation revealed from the occupancy behavior verification stage (Section 2.6.4) was finding that occupants use mobile electric and gas heaters. There was a difficulty to match the simulated electricity use values with the measured ones during calibration for December, January, and 

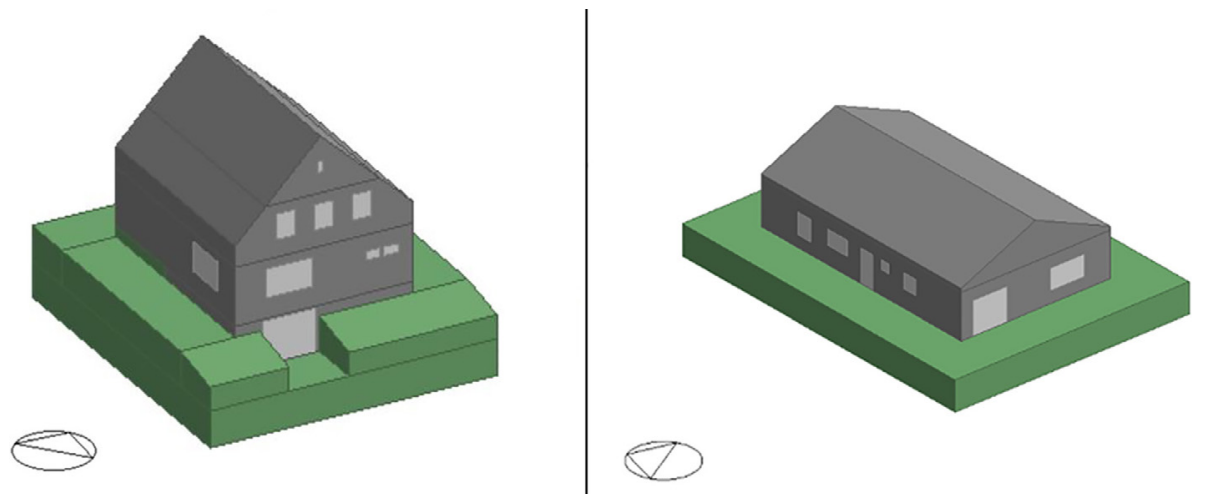

Fig. 8. Typology A and B in 3D view.

Table 3

Heating demand, electricity demand, and energy use intensity.

\begin{tabular}{|c|c|c|c|c|c|c|}
\hline $\begin{array}{l}\text { Buildings } \\
\text { Type }\end{array}$ & $\begin{array}{l}\text { Average heating energy demand [kWh/ } \\
\mathrm{m}^{2} / \text { year] }\end{array}$ & Variance & $\begin{array}{l}\text { Average electricity demand [kWh/ } \\
\mathrm{m}^{2} / \text { year] }\end{array}$ & Variance & $\begin{array}{l}\text { Average energy use intensity [ } \mathrm{kWh} / \\
\mathrm{m}^{2} / \text { year] }\end{array}$ & Variance \\
\hline Archetype A & 148.7 & 33.5 & 17.7 & 7.6 & 166.4 & \\
\hline Archetype B & 139.8 & 38.4 & 14.9 & 5 & 154.7 & \\
\hline
\end{tabular}
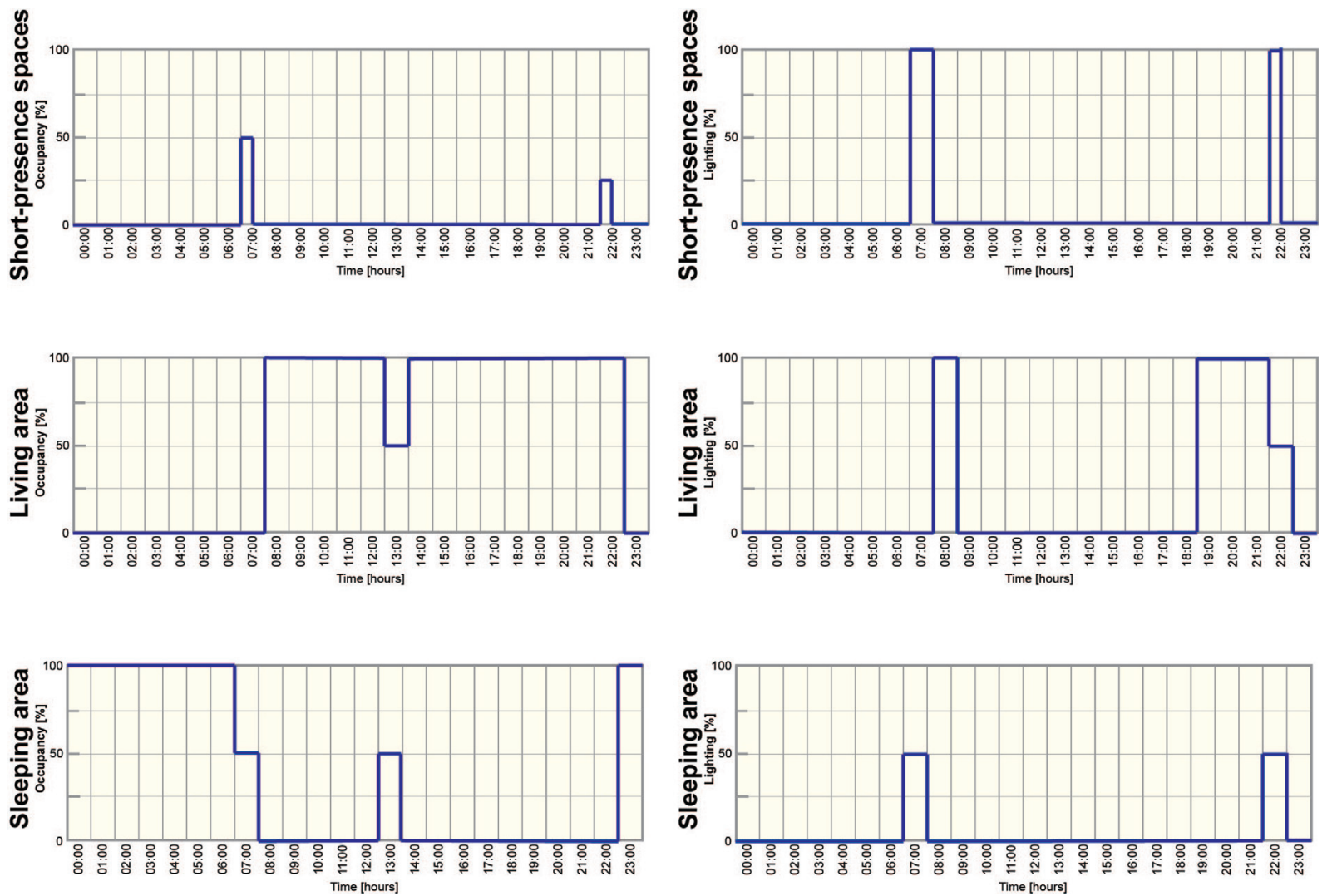

Fig. 9. Occupation schedule.

February. The backtracking of survey respondents, logbooks, and post-hoc interviews revealed that more than $25 \%$ of occupants used electric heating, electric heating mobile convectors, and fan- assisted heaters. The main reason was to improve the personalized thermal comfort and comfort perception. The use of electric heating devices justified the calibration problem and allowed to 
Table 4

Occupation status of apartment members in a typical apartment for five family members.

\begin{tabular}{|c|c|c|c|c|c|}
\hline \multirow[b]{2}{*}{ 2018/2019 } & \multirow[b]{2}{*}{ Member } & \multicolumn{2}{|c|}{ Archetype A } & \multicolumn{2}{|c|}{ Archetype B } \\
\hline & & Senior 1 & Senior 2 & Senior 1 & Adult 2 \\
\hline- & Status & Pensioned & Pensioned & Full-time & Pensioned \\
\hline Days at home & 06:00-09:00 & Often & Often & Often & Often \\
\hline \multirow{5}{*}{ Weekday } & 09:00-12:00 & Often & Often & Seldom & Often \\
\hline & $12: 00-15: 00$ & Regularly & Regularly & Seldom & Regularly \\
\hline & $15: 00-18: 00$ & Often & Often & Seldom & Often \\
\hline & $18: 00-23: 00$ & Often & Often & Often & Often \\
\hline & $23: 00-06: 00$ & Often & Often & Often & Often \\
\hline Days at home weekend* & & Often & Often & Regularly & Regularly \\
\hline
\end{tabular}

*The same schedules for a weekday and the weekend were used with slight differences.

Table 5

Holidays schedules for the year 2021.

\begin{tabular}{llll}
\hline Name & Start date & End date & Number of days \\
\hline Easter Holidays & $30 / 03 / 2021$ & $05 / 04 / 2018$ & 7 \\
Summer Holidays & $01 / 08 / 2018$ & $15 / 08 / 2018$ & 15 \\
All Saints'Day Holidays & $28 / 10 / 2018$ & $05 / 11 / 2018$ & 7 \\
Christmas Holidays & $24 / 12 / 2018$ & $01 / 01 / 2018$ & 7 \\
\hline
\end{tabular}

increase the curves fit shown in Figs. 10 and 11. The monitoring of indoor quality parameters in both households confirmed several behavioral estimations concerning the heating setpoints and occupancy presence and patterns.

\section{Discussion}

Benchmarking allows characterizing existing buildings to enable reliable simulations and realistic future renovation scenarios. In this section, we discuss the study findings and position them regarding the state-of-the-art.

\subsection{Summary of the main findings}

Two reference models representing 633.702 post-WWII single-family houses in Belgium were created and validated. As shown in Table 9, archetype A has an average energy use intensity of $166 \mathrm{kWh} / \mathrm{m}^{2} /$ year and represents detached single-family houses built between 1945 and 1969. Archetype B has an average energy use intensity of $155 \mathrm{kWh} / \mathrm{m}^{2} /$ year and represents detached single-family houses built between 1970 and 1990 . Both archetypes represent buildings built before or during the oil crisis in the 1970s, thus before any building energy efficiency requirement.
The results of the benchmarking of the two reference models are summarized in Table 9. The buildings hardly comply with any building energy efficiency criteria. The heat gains are low due to the small size of windows (see WWR values) and external roller shutters in most households. However, the heat losses are remarkably high, as indicated by the high U-value of the envelope and poor airtightness. The air change rate at $50 \mathrm{~Pa}$ pressure was 14.5 and $13.8 \mathrm{ACH}$, both benchmark models, respectively. Each building is equipped with one or two chimneys that act as passive stack ventilation. The openings in the envelope cause the leakage flow to be high. Also, the internal gains are low due to the low occupancy density. Older people choose to remain in their large homes, which host in the past 2-3 children on average. The most important and tangible outcomes of both building performance characteristics are described below:

- One thousand three hundred twenty-eight representative single-family households have been selected nationally (out of 633,702 ) with an automated algorithm using GIS database (Belgian cadaster).

- Two multizonal energy benchmark models were created in EnergyPlus based on the representative building stock performance and were calibrated based on the ASHRAE BESTEST requirements

- A dataset containing the physical and thermal characteristics of more than 1300 buildings has been created

- The average annual electricity use intensity for archetypes A and $B$ is $17,7 \mathrm{kWh} / \mathrm{m}^{2} /$ year and $14,9 \mathrm{kWh} / \mathrm{m}^{2} /$ year.

- The average heating use intensity for archetypes A and B is $148.7 \mathrm{kWh} / \mathrm{m}^{2} /$ year and $139.8 \mathrm{kWh} / \mathrm{m}^{2} /$ year.

- The EPC rating for archetypes A and B is F and E, respectively, higher than expected ( $G$ rating).

Table 6

Appliances found in typical Belgian post-WWII single-family houses.

\begin{tabular}{|c|c|c|c|c|c|}
\hline Appliance & Watt-hour & Daily Operating Hours & Appliance & Watt-hour & Daily Operating Hours \\
\hline Furnace fan & 50 & 1.5 & HD Television & 50 & 5 \\
\hline Coffee machine & 600 & 0.2 & Deep Fryer & 1500 & 0.05 \\
\hline Microwave & 1500 & 0.2 & Washing machine & 680 & 0.8 \\
\hline Mobile charger & 5 & 24 & Refrigerator (2 doors) & 95 & 24 \\
\hline Phone charger & 3 & 3 & Kettle & 1500 & 0.2 \\
\hline Built in Oven & 300 & 0.1 & PC/ Laptop/Tablets & $150 / 60 / 40$ & 2 \\
\hline Electric Iron & 1100 & 0.1 & Freezer & 15 & 24 \\
\hline Vacuum cleaner & 330 & 0.05 & Radio & 15 & 0.1 \\
\hline Clothes Dryer & 561 & 0.8 & Dishwasher & 720 & 1 \\
\hline DVD/CD Player & 40 & 0.05 & Electric Stove & 650 & 0.9 \\
\hline
\end{tabular}


Table 7

MBE and CV(RMSE) of the monthly energy heating and electricity consumption.

\begin{tabular}{lll}
\hline Statistical indices & MBE (\%) & CV(RMSE) (\%) \\
\hline Typology A Monthly calibration (Natural gas) & 1,6 & 0,02 \\
Typology A Monthly calibration (Electricity) & 2,75 & 9,5 \\
Typology B Monthly calibration (Natural gas) & 0,1 & 0,38 \\
Typology B Monthly calibration (Electricity) & 3,1 & 10,8 \\
\hline
\end{tabular}

- The building envelope air permeability was very poor, with an average of 13.8 and $14.5 \mathrm{vol} / \mathrm{h}$ at $50 \mathrm{~Pa}$, for both archetypes, respectively. Several chimneys, cracks around openings, and added extensions, such as verandas, are the leading cause of this problem.

- Most windows are double glazed due to window retrofits that took place before the year 2000. However, the overall windows performance is low, with a high conductivity value ranging around $2.8 \mathrm{~W} / \mathrm{m}^{2} \mathrm{~K}$.

- Similarly, the envelope conductivity, around $1.7 \mathrm{~W} / \mathrm{m}^{2} \mathrm{~K}$ for walls and $1.3 \mathrm{~W} / \mathrm{m}^{2} \mathrm{~K}$ for roofs, is high. Surprisingly, more than $40 \%$ of households has poorly insulated bitumen felt shingles roofs.

- The households are dominated by elderly occupants ( $>65$ years old) and have a low occupancy density with average households area of $250-300 \mathrm{~m}^{2}$ and $180-240 \mathrm{~m}^{2}$ for archetypes A and B.

\subsection{Strengths and limitations of the study}

The renovation of the post-WWII residential building stock offers many opportunities to neutralize the building sector's carbon emissions across Europe [4]. Therefore, building benchmarking is the basis for energy performance assessment approaches to reduce energy use and align with minimum performance requirements [89]. Using calibrated building simulation provides insights into the performance issues applicable across Europe. Moreover, the detailed characterization of the building performance allows closing the performance gap.

In this study, an essential vintage of single-family households was characterized by actual monthly energy use data for natural gas and electricity with four years of monitoring (2016 and 2019). The study identified a type of owners and age group that are not often studied in the literature [22]. Also, we are not aware of a West European study that characterized such a sample size of post-WWII single-family houses using GIS and fieldwork data collection techniques. Most of the existing studies found in the literature are based on statistical methods to create theoretical benchmark models [17]. The study results present a representative and accurate characterization of energy efficiency and occupant behavior. Using building performance simulation enables a systematic identification and classification of the performance gap's root causes for any future renovation scenario.

A novel approach was used to identify and verify performance issues using evidence-based calibration to increase the newly created models' confidence and accuracy. With the help of a mixed methodological approach, previously used [90], the study was able to survey house owners, collect energy bills, perform walkthrough audits and more importantly, perform in-situ blower door test and conductivity monitoring. The presence of smart meters in many households due to photovoltaic installation helped verify the monthly energy profiles. A systematic and structured data collection approach with a team of 15 participants allowed triangulating the data sources. The triangulation approach allowed revealing insights on the occupancy behavior and building energy efficiency.

Table 8

Normalised energy use intensity for archetypes A and B between 2016 and 2019.

\begin{tabular}{|c|c|c|c|c|c|c|c|c|}
\hline \multirow[b]{2}{*}{ Energy use intensity in $\mathrm{kWh} / \mathrm{m}^{2} /$ year } & \multicolumn{2}{|l|}{$\begin{array}{l}2016 \\
\text { A B }\end{array}$} & \multicolumn{2}{|l|}{$\begin{array}{l}2017 \\
\text { A B }\end{array}$} & \multicolumn{2}{|l|}{$\begin{array}{l}2018 \\
\text { A B }\end{array}$} & \multicolumn{2}{|l|}{$\begin{array}{l}2019 \\
\text { A B }\end{array}$} \\
\hline & 174 & 158 & 168 & 169 & 165 & 146 & 156 & 143 \\
\hline HDD base temperature $15^{\circ} \mathrm{C}[64]$ & 2556 & & 2448 & & 2383 & & 2379 & \\
\hline The difference compared to the average 2442 HDD (2016-2019) & $-4 \%$ & & $+0 \%$ & & $+2.5 \%$ & & $+3.4 \%$ & \\
\hline Normalized energy use intensity $\left(\mathrm{kWh} / \mathrm{m}^{2} /\right.$ year) & 167 & 152 & 168 & 169 & 169 & 150 & 161 & 148 \\
\hline
\end{tabular}

Table 9

Summary of input parameters for both benchmark models after calibration.

\begin{tabular}{|c|c|c|c|}
\hline Model input measures & & Typology A & Typology B \\
\hline \multirow[t]{7}{*}{ Envelope } & Window to Wall Ratio (WWR in \%) & $12 \%$ & $10 \%$ \\
\hline & Solar Heat Gain Coefficient (SHGC) & 0.74 & 0.60 \\
\hline & Light transmittance (LT) & 0.80 & 0.70 \\
\hline & Solar protection (External) & Roller Shutters & Roller Shutters \\
\hline & Windows $\mathrm{U}$ Value $=\left[\mathrm{W} / \mathrm{m}^{2} \mathrm{~K}\right)$ & 2.90 & 2.76 \\
\hline & Roof $\mathrm{U}$ Value $=\left[\mathrm{W} /\left(\mathrm{m}^{2} \mathrm{~K}\right)\right]$ & 1.25 & 1.4 \\
\hline & Airtightness (at $50 \mathrm{~Pa} \mathrm{~m}^{3} / \mathrm{h}-\mathrm{m}^{2}$ ) & 290 or $14.5 \mathrm{ACH}$ & 276 or $13.8 \mathrm{ACH}$ \\
\hline \multirow[t]{4}{*}{ Heating system, ventilation, and air conditioning } & COP Heating system & 0.76 & 0.80 \\
\hline & Temperature set point $\left[{ }^{\circ} \mathrm{C}\right]$ for heating & 23 & 22 \\
\hline & Heating system & Gas-fired boiler & Gas-fired boiler \\
\hline & Heating fuel & Natural gas & Natural gas \\
\hline Lighting & Lighting power density $\left[\mathrm{W} / \mathrm{m}^{2}\right]$ & $8-12$ & $8-12$ \\
\hline \multirow[t]{3}{*}{ Occupancy } & Number of people & 2 & 2 \\
\hline & Occupancy Density [ $\mathrm{m}^{2} /$ person] & 129,5 & 74 \\
\hline & Occupancy schedule & See Fig. 9 & See Fig. 9 \\
\hline Total & Average consumption $\left[\mathrm{kWh} / \mathrm{m}^{2} /\right.$ year] & 166 & 155 \\
\hline
\end{tabular}



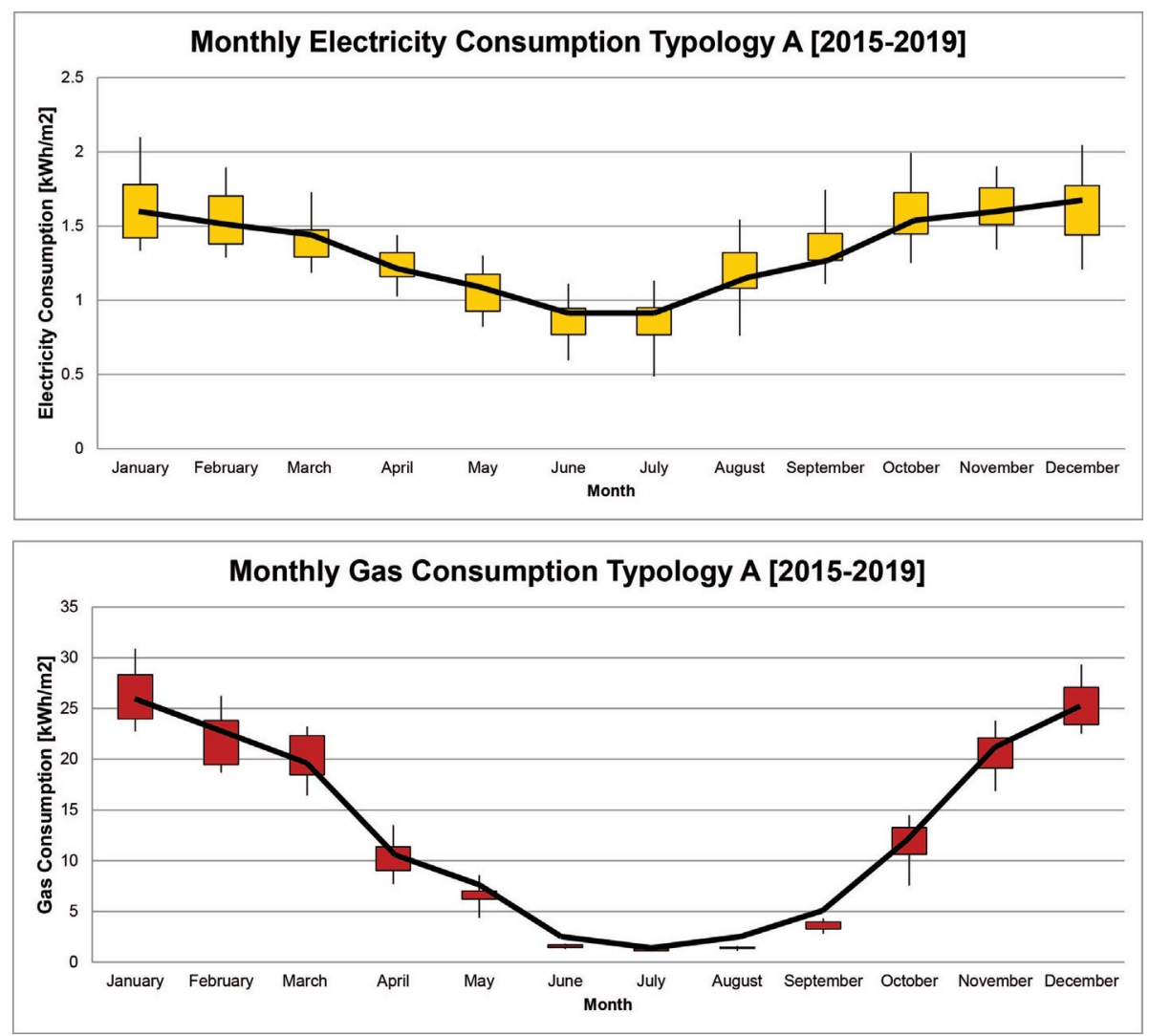

Fig. 10. Surveyed and simulated monthly electricity and gas use of typology A.
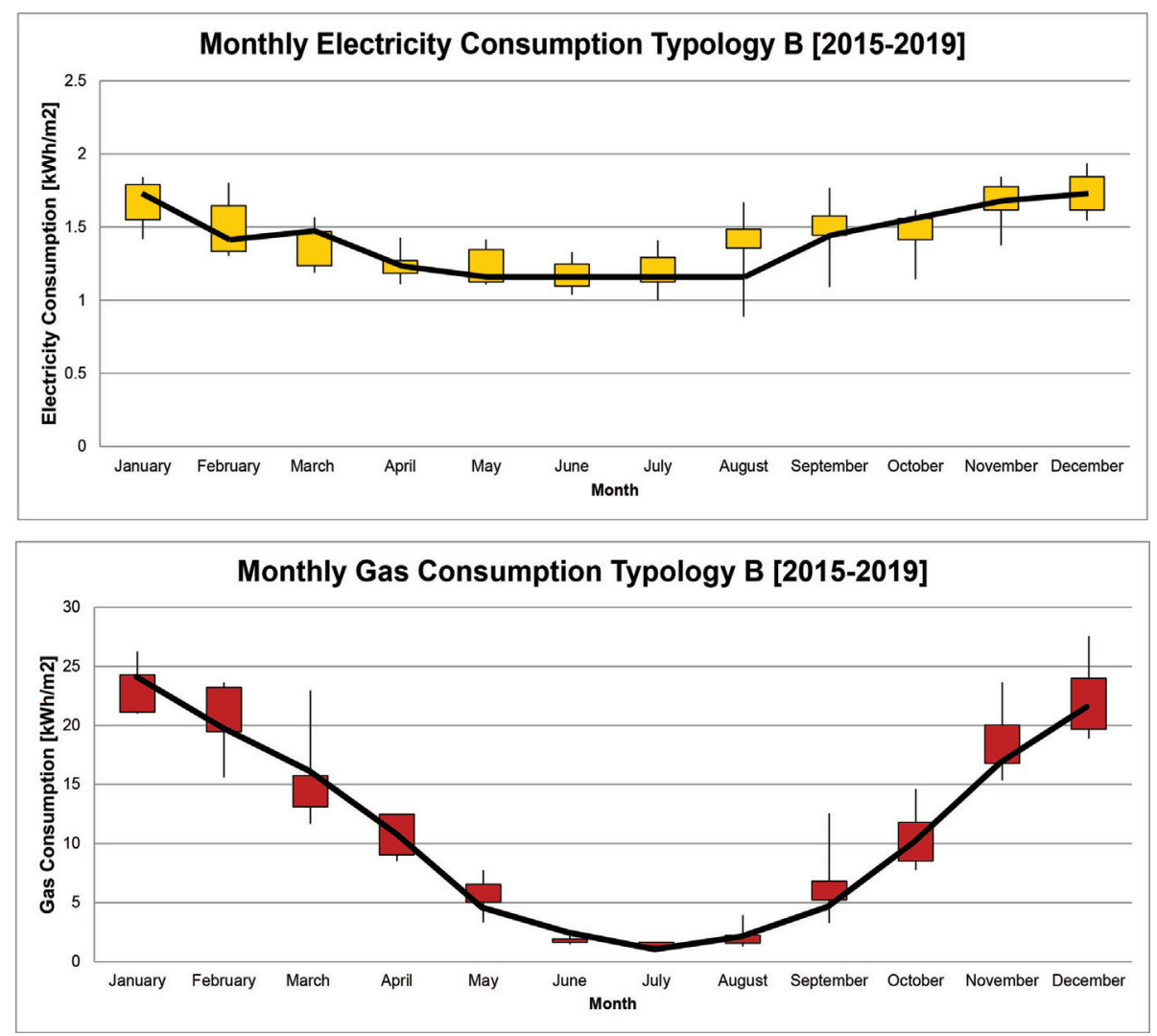

Fig. 11. Surveyed and simulated monthly electricity and gas use of typology B. 
Despite the long investigation period that covered 5-years, the results are valuable, and the dataset will be further analyzed and exploited.

This study identified several lessons that can potentially be used to inform and improve current building renovation practices. However, the paper has some limitations, including the thermal comfort characterization. Therefore, a detailed comfort characterization is still underway. The poor envelope performance, air conditioners, mobile electric heaters, and the absence of mechanical ventilation systems were associated with overheating and winter discomfort problems. A thermal comfort assessment paper will deal with the indoor thermal quality issues based on the survey answers and dataset developed in this study.

\subsection{Implication for the practice and future research}

Belgium and many other industrial countries are facing an aging population. This study found that most households are too large concerning the low occupancy rate of two occupants per household. Unfortunately, the occupants of most of the investigated households ( $>65$ years of age) did not go through a deep renovation despite their financial capacity. On the other hand, the transfer of ownership of post-WWII households already started and intensified during the next 30 years. If Belgium and Europe wish to achieve the 2050 carbon emission reduction targets, new house owners and nuclear families shall occupy those households and pay for the renovation cost. However, it will be difficult to develop targeted renovation policies and subsidy programs without an accurate characterization. The study findings add to the evidence found in the literature [91] that nuclear families renovate their households at the beginning of their life [92] and not after being pensioned. The survey findings on usufrucuary ownership status confirm that too. Therefore, the moment of buying the post-WWII household will be crucial to implement any deep renovation.

In this context, local governments must prepare fiscal and financial regulation packages to encourage deep renovation endeavors. The decarbonizing of heating in post-WWII residential buildings requires policies, priorities, and timelines to ensure Belgium gets on track to achieve the carbon neutrality targets by 2050. Future research should also explore cost-effective renovation strategies and solutions based on the European Cost Optimality approach [93]. A detailed short-term and long-term road map on the renovation packages should be developed on the national level. Without a road map, it will address the renovation barriers that go beyond issues. Encouraging housing owners to renovate the postWWII households and motivating them is part of any states' role. The development of an ecosystem of small and middle-size renovation enterprises with skilled labor is a vital element.

Finally, we invite international researchers to develop new occupancy schedules for senior adults beyond the limitations of ISO 18523 [61] and ISO 17772 [85]. The existing standards do not indicate how the elderly behave in the living environment. As a way to support this research endeavor, this study can be considered as starting point for further research on the development of senior adult occupancy profiles for building performance simulation.

\section{Conclusions}

The energy characterization of 1328 post-WWII single-family houses located in the three regions of Belgium (Brussels, Flanders, and Wallonia) took place based on four-year measurement data (2016-2019). To the authors' knowledge, this is the first energy characterization study of post-WWII single-family houses that have been reported from this part of Europe. The following key findings describe the study outcomes:

- Two accurate energy models representing 633,702 current households to predict energy use intensity and energy efficiency of single-family households built 1945 to 1990.

- The energy use characterization indicated that the average energy use intensity of archetype $A$ is $155 \mathrm{kWh} / \mathrm{m}^{2} /$ year $166 \mathrm{kWh} / \mathrm{m}^{2} /$ year for archetype B.

- The EPC rating of archetype $\mathrm{A}$ is $\mathrm{F}$, and the rating of archetype $\mathrm{B}$ is $\mathrm{E}$.

- Two representative archetypes were identified and created in EnergyPlus software after several iteration rounds. The models were calibrated according to ASHRAE Guideline 14 using two indices to evaluate the goodness-of-fit of the building energy model.

- Rigorous validation measures consolidated the model input assumptions, namely (1) weather normalization, (2) envelope conductivity and airtightness, and (3) occupancy behavior observations.

The poor envelope performance and large heated house volumes/spaces appeared to be the most influential factor to the high energy use intensity. Despite that, the households were dominated on average by senior couples (>65 years old) the energy use remained relatively high. Consequently, the poor envelop physical and thermal properties resulted in discomfort problems and significant reliance on personalized plugged electric heating. Thus, the increased consumption of gas and electricity urges the need for renovation deep renovation (insulation, double glazing, blinds, mechanical ventilation, etc.). Further research aiming to characterize other post-WWII archetypes better and develop multi-objective renovation scenarios appears necessary to tackle carbon neutrality issues in existing households.

\section{Declaration of Competing Interest}

The authors declare that they have no known competing financial interests or personal relationships that could have appeared to influence the work reported in this paper.

\section{Acknowledgment}

The authors express their thanks to all survey respondents. The Walloon Region partially funded this research under the call 'Actions de Recherche Concertées 2019 (ARC)' and the project OCCuPANt, on the Impacts Of Climate Change on the indoor environmental and energy PerformAnce of buildiNgs in Belgium during summer. The authors would like to acknowledge the Walloon Region and Liege University for funding gratefully. We would also like to recognize the Sustainable Building Design Lab for the use of monitoring equipment in this research and the valuable support during the experiments and data analysis.

\section{Appendix}




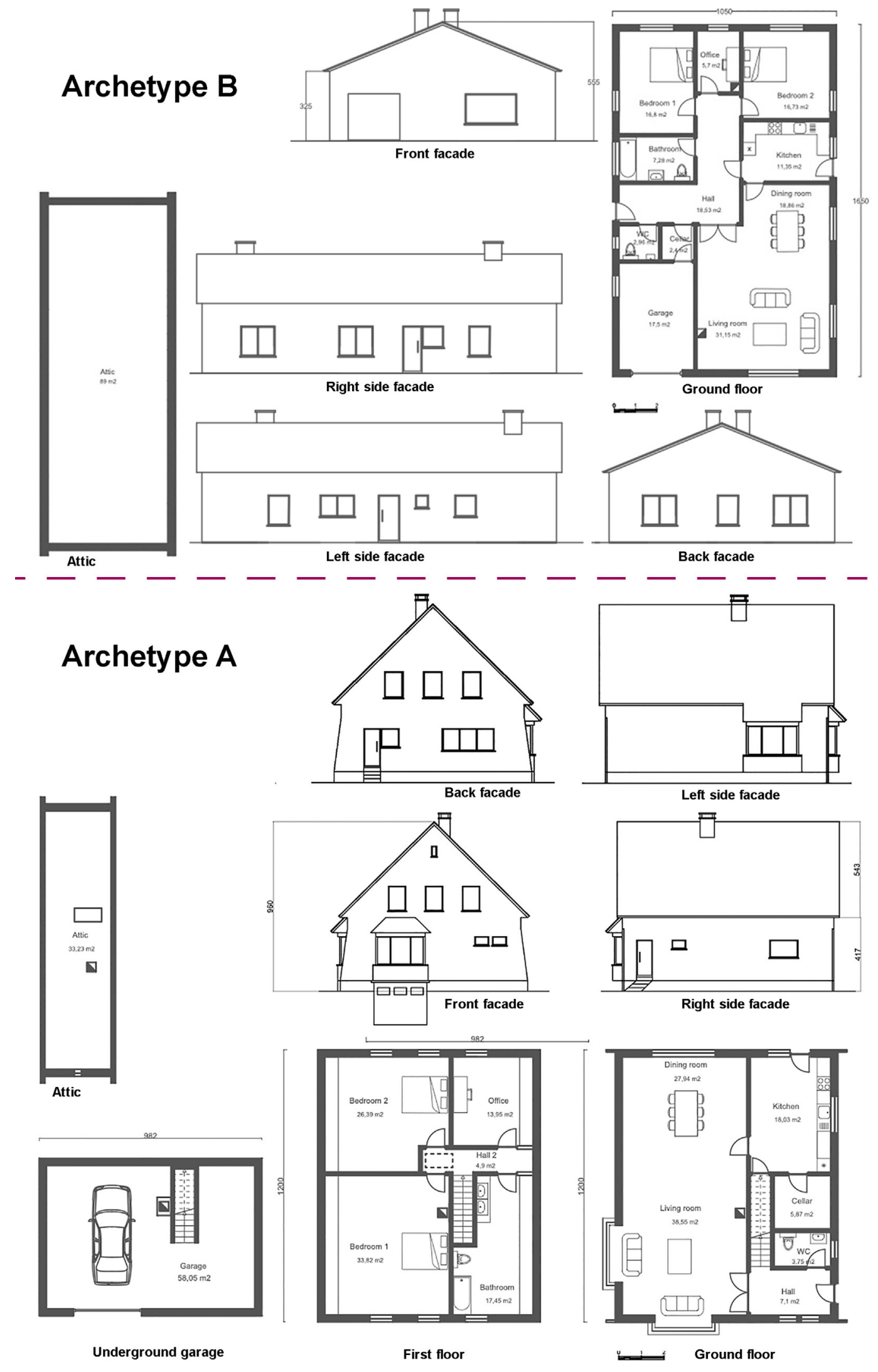

Fig. A1. floor plans and facades of archetype A and B. 


\section{References}

[1] IEA, "Shares of residential energy consumption by end use in selected IEA countries," 2018. https://www.iea.org/data-and-statistics/charts/shares-ofresidential-energy-consumption-by-end-use-in-selected-iea-countries-2018.

[2] EU, "State of the Union: Commission raises climate ambition and proposes 55\% cut in emissions by 2030." European Commission, 2020, Accessed: Feb. 16, 2021. [Online]. Available: https://ec.europa.eu/commission/presscorner/ detail/en/IP_20_1599.

[3] EU, "Questions and Answers on the Renovation Wave," 2020. https://ec. europa.eu/commission/presscorner/detail/en/qanda_20_1836 (accessed Feb. 16, 2021).

[4] F. Meijer, L. Itard, M. Sunikka-Blank, Comparing European residential building stocks: performance, renovation and policy opportunities, Build. Res. Inf. 37 (5-6) (2009) 533-551.

[5] G. Ruellan, M. Cools, S. Attia, Analysis of the determining factors for the renovation of the Walloon residential building stock, Sustainability 13 (2021) 21220.

[6] D.A. Pohoryles, C. Maduta, D.A. Bournas, L.A. Kouris, Energy performance of existing residential buildings in Europe: A novel approach combining energy with seismic retrofitting, Energy Build. 223 (2020).

[7] "Émissions par secteur," Klimaat | Climat. https://climat.be/enbelgique/climat-et-emissions/emissions-des-gaz-a-effet-de-serre/emissionspar-secteur (accessed Dec. 08, 2020).

[8] FGOV, “CSTC sur base du census des logements.” 2011, Accessed: Feb. 16, 2021. [Online]. Available: https://www.census2011.be/download/downloads_fr. html.

[9] R. Hendron, R. Anderson, C. Christensen, M. Eastment, and P. Reeves, "Development of an energy savings benchmark for all residential end-uses," National Renewable Energy Lab., Golden, CO (US), 2004

[10] P. Torcelini et al., "DOE commercial building benchmark models," National Renewable Energy Lab.(NREL), Golden, CO (United States), 2008.

[11] N. Fumo, P. Mago, R. Luck, Methodology to estimate building energy consumption using EnergyPlus Benchmark Models, Energy Build. 42 (12) (2010) 2331-2337.

[12] US DOE, "Residential Prototype Building Models," Building Energy Codes Program, 2020. https://www.energycodes.gov/development/residential/ iecc models (accessed Jan. 31, 2021).

[13] US DOE, "Commercial Prototype Building Models," Building Energy Codes Program, 2020. https://www.energycodes.gov/development/commercial/ prototype models (accessed Jan. 31, 2021).

[14] M. Deru et al., "US Department of Energy commercial reference building models of the national building stock," 2011.

[15] K. Bettgenhäuser, Integrated Assessment Modelling for Building Stocks: A Technical, Economical and Ecological Analysis. Ingenieurwiss. Verlag, 2013.

[16] W. Cyx , N. Renders, M. Van Holm en S. Verbeke, "IEE TABULA - Typology Approach for Building Stock Energy Assessment." 2011, [Online]. Available: https://episcope.eu/fileadmin/tabula/public/docs/scientific/ BE_TABULA_ScientificReport_VITO.pdf.

[17] IWU, "EPISCOPE and TABULA," Monitor Progress Towards Climate Targets in European Housing Stocks, 2016. https://episcope.eu/welcome/ (accessed Jan. 31, 2021).

[18] "Directive 2010/31/EU of the European Parliament and of the Council of 19 May 2010 on the energy performance of buildings," p. 23.

[19] S. P. Corgnati, E. Fabrizio, M. Filippi, and V. Monetti, "Reference buildings for cost optimal analysis: Method of definition and application," Appl. Energy, vol. 102, pp. 983-993, Feb. 2013, doi: 10.1016/j.apenergy.2012.06.001.

[20] "Commission Delegated Regulation (EU) No 244/2012 of 16 January 2012 supplementing Directive 2010/31/EU of the European Parliament and of the Council on the energy performance of buildings by establishing a comparative methodology framework for calculating cost-optimal levels of minimum energy performance requirements for buildings and building elementsText with EEA relevance," p. 19

[21] S. Attia, A. Mustafa, G. Nicolas, M. Popineua, M. Cuchet, and N. Gulirmak, "Developing two benchmark models for post-world war II residential buildings," Energy Build., p. 101, 2021.

[22] A. Berndgen-Kaiser, R. Fox-Kämper, M. Wiechert, Post-war single-family houses in europe under pressure? A demographic and economic framework for the future market of elder single-family housing neighbourhoods, ArticuloJ. Urban Res. (2016).

[23] W. Bervoets, M. van de Weijer, The Future of the Post-War Single-family House. The case of Flanders, 2015.

[24] H. Ben, K. Steemers, Modelling energy retrofit using household archetypes, Energy Build. 224 (2020).

[25] M.F. Touchie, K.D. Pressnail, Using suite energy-use and interior condition data to improve energy modeling of a 1960s MURB, Energy Build. 80 (2014) 184194.

[26] S. Attia, A. Evrard, E. Gratia, Development of benchmark models for the Egyptian residential buildings sector, Appl. Energy 94 (2012) 270-284.

[27] S. Attia, N. Shadmanfar, F. Ricci, Developing two benchmark models for nearly zero energy schools, Appl. Energy 263 (2020).

[28] A. Guideline, Guideline 14-2002, measurement of energy and demand savings, Am. Soc. Heat. Vent. Air Cond. Eng. Atlanta Ga. (2002).

[29] S. Attia, Net zero energy buildings (nzeb), 1st edition. Cambridge, MA: Elsevier, 2018.
[30] A. Tereci, S.T.E. Ozkan, U. Eicker, Energy benchmarking for residential buildings, Energy Build. 60 (2013) 92-99.

[31] M. Ghajarkhosravi, Y. Huang, A.S. Fung, R. Kumar, V. Straka, Energy benchmarking analysis of multi-unit residential buildings (MURBs) in Toronto, Canada, J. Build. Eng. 27 (2020).

[32] Bruxelles Environnement, "Rapport à la Commission relatif l'établissement de niveaux optimaux en fonction des coûts des exigences minimales en matière de performance énergétique," Bruxelles Environnement, Brussels, Belgium, May 2013.

[33] J. Van der Veken, J. Creylman, and T. Lenaerts, “STUDIE NAAR KOSTENOPTIMALE NIVEAUS VAN DE MINIMUMEISEN INZAKE ENERGIEPRESTATIES VAN NIEUWE RESIDENTIËLE GEBOUWEN," Kenniscentrum Energie, Geel, Belgium, Jun. 2015. Accessed: Oct. 02, 2021. [Online]. Available: https://www.energiesparen.be/sites/default/files/ atoms/files/verslag_NB_20150703.pdf.

[34] C. Leveau, M. Cherdon, M. Vismara, and B. Huberlant, "Détermination du niveau de performance énergétique optimal des bâtiments en fonction des coûts," 3E, Brussels, Belgium, PR109008, Dec. 2018. Accessed: Oct. 02, 2021. [Online]. Available: https://energie.wallonie.be/servlet/Repository/cozeb-2rapport-final.pdf?ID=54806.

[35] E. Fabrizio, V. Monetti, Methodologies and advancements in the calibration of building energy models, Energies 8 (4) (2015) 2548-2574.

[36] P. Caputo, G. Pasetti, Boosting the energy renovation rate of the private building stock in Italy: Policies and innovative GIS-based tools, Sustain. Cities Soc. 34 (2017) 394-404.

[37] P. Femenías, K. Mjörnell, L. Thuvander, Rethinking deep renovation: The perspective of rental housing in Sweden, J. Clean. Prod. 195 (2018) 1457-1467.

[38] T. Johansson, T. Olofsson, M. Mangold, Development of an energy atlas for renovation of the multifamily building stock in Sweden, Appl. Energy 203 (2017) 723-736.

[39] F.P. Chantrelle, H. Lahmidi, W. Keilholz, M. El Mankibi, P. Michel, Development of a multicriteria tool for optimizing the renovation of buildings, Appl. Energy 88 (4) (2011) 1386-1394.

[40] P. Peda, G. Grossi, M. Liik, Do ownership and size affect the performance of water utilities? Evidence from Estonian municipalities, J. Manag. Gov. 17 (2) (2013) 237-259

[41] J. Weiss, E. Dunkelberg, T. Vogelpohl, Improving policy instruments to better tap into homeowner refurbishment potential: Lessons learned from a case study in Germany, Energy Policy 44 (2012) 406-415.

[42] C. Wilson, L. Crane, G. Chryssochoidis, Why do homeowners renovate energy efficiently? Contrasting perspectives and implications for policy, Energy Res. Soc. Sci. 7 (2015) 12-22.

[43] FPS, "Belgian Cadastral Parcel Data," FPS Finances - General Administration of Patrimonial Documentation (GAPD), Brussels, Belgium, 2016

[44] A.M.R. Nishimwe, S. Reiter, Building heat consumption and heat demand assessment, characterization, and mapping on a regional scale: A case study of the Walloon building stock in Belgium, Renew. Sustain. Energy Rev. 135 (2021).

[45] DGO4, "Belgian Energy Efficiency Action Plan," Namur, Belgium, 2014. Accessed: Nov. 02, 2021. [Online]. Available: https://ec.europa.eu/energy/ sites/ener/files/documents/Belgium\%20NEEAP.pdf.

[46] A. Deneyer, Efficacité énergétique des bâtiments : un peu d'histoire, BBRI (2006).

[47] C.R. Wilson Van Voorhis, B.L. Morgan, Understanding power and rules of thumb for determining sample sizes, Tutor. Quant. Methods Psychol. 3 (2) (Sep. 2007) 43-50, https://doi.org/10.20982/tqmp.03.2.p043.

[48] Bruxelles Environnement, "Register of EPB certificates for Brussels housing." Bruxelles Environnement, Brussels, Belgium, Nov. 02, 2021, [Online]. Available: https://www.peb-epb.brussels/certificats-certificaten/.

[49] P. Voigt, A. Von dem Bussche, The eu general data protection regulation (gdpr), Pract. Guide 1st Ed Cham Springer Int. Publ. 10 (2017) 3152676.

[50] Wikipedia, “Loi de Taeye," Wikipedia. Jul. 20, 2020, [Online]. Available: https:// fr.wikipedia.org/wiki/Loi_de_Taeye\#: :text=que\%20les\%20logements.-, Contenu,acquisition\%20de\%20petites\%20propri\%C3\%A9t\%C3\%A9s\% 20terriennes\%20.\&text=En\%20effet\%2C\%20pr\%C3\%A8s\%20de\%2090,construire \%20qu'avec\%20des\%20emprunts.

[51] C. Vandermotten, Théorie géographique et empirie historique: site, situation et auto-reproduction spatiale. De Bruxelles à la ville européenne, Rev. Belge Philol. Hist. 89 (2) (2011) 841-860.

[52] J. Puissant, L'exemple belge: l'habitat privé, la maison individuelle l'emportent sur l'habitat collectif, Rev. Nord 1 (2008) 95-116.

[53] M. Reynebeau, Histoire belge: 1830-2005. Lannoo Uitgeverij, 2005.

[54] FAB, "Repères historiques," FÉDÉRATION DES SOCIÉTÉS D'ARCHITECTES DE BELGIQUE, 2019. http://www.fab-arch.be/fr/fab/historique\#: :text=La\%20Loi \%20de\%201963\%20cr\%C3\%A9ant,1980\%2C\%20la\%20Belgique\%20se\%20r\%C3\% A9gionalise. (accessed Nov. 02, 2021).

[55] L. Flouquet, La petite maison familiale, Art \& Technique (1950).

[56] S. Van de Voorde, I. Bertels, and I. Wouters, Post-war building materials in housing in Brussels 1945-1975. Brussels, Belgium: VUB, 2015.

[57] S. Van de Voorde, I. Bertels, and I. Wouters, "The emergence of a new generation of building products in post-war Belgium: the case of lightweight concrete," in Proceedings of the First Conference of the Construction History Society: Queens' College, Cambridge, 11-12 April 2014, 2014, pp. 423-433.

[58] A. O'Neill, "Total fertility rate in Belgium from 1800 to 2020," Statista, Brussels, Belgium, 2020. [Online]. Available: https://www.statista.com/statistics 1033487/fertility-rate-belgium-1800-2020/. 
[59] F. Nicolai, Archibelge - La loi De Taeye, Belgium, Brussels, 2016.

[60] M. Krarti, Energy audit of building systems: an engineering approach. CRC press, 2020

[61] ISO, "18523-2:2016. Energy performance of buildings - Schedule and condition of building, zone and space usage for energy calculation - Part 2: Residential buildings." International Organization for Standardization, 2016.

[62] DOE, "EnergyPlus." Department of Energy, 2021, Accessed: Dec. 02, 2021. [Online]. Available: https://energyplus.net/.

[63] M. Kottek, J. Grieser, C. Beck, B. Rudolf, and F. Rubel, "World map of the Köppen-Geiger climate classification updated," 2006.

[64] eurostat, "Cooling and heating degree days by NUTS 2 regions - annual data," European Commission, Brussels, Belgium, 2021.

[65] IRM, "Royal Meteorological Institute of Belgium." 2021.

[66] Ashrae, "ASHRAE standart 140-2017 - standart method of test for evaluation of building energy analysis programs.” 2017.

[67] C.J. Hopfe, J.L. Hensen, Uncertainty analysis in building performance simulation for design support, Energy Build. 43 (10) (2011) 2798-2805.

[68] E. ASHRAE, "ASHRAE Handbook Fundamentals. Atlanta, GA, American Society of Heating," Refrig. Air-Cond. Eng., 2013.

[69] A. Makhmalbaf, V. Srivastava, and N. Wang, "Simulation-based weather normalization approach to study the impact of weather on energy use of buildings in the US," in 13th Conference of international building performance simulation association, 2013, pp. 1436-1444.

[70] A. Bossaer, J. Demeester, P. Wouters, B. Vandermarke, and W. Vangroenweghe, "Airtightness performances in new Belgian dwellings," in DOCUMENT-AIR INFILTRATION CENTRE AIC PROC, 1998, pp. 77-84.

[71] SPW, "Stratégie Wallonne de rénovation énergétique à long terme du bâtiment," 2020.

[72] EC, 13829 Thermal performance of buildings-Determination of air permeability of buildings-Fan pressurization method, Eur. Comm. Standard. (2016).

[73] A. K. en Innovatie, N. Gate, K. A. II-laan, and G. De Poorter, "FOD ECONOMIE, KMO, MIDDENSTAND \& ENERGIE."

[74] A. Rasooli, L. Itard, In-situ characterization of walls' thermal resistance: An extension to the ISO 9869 standard method, Energy Build. 179 (2018) 374383.

[75] H. Hens, A. Janssens, W. Depraetere, J. Carmeliet, J. Lecompte, Brick cavity walls: a performance analysis based on measurements and simulations, J. Build. Phys. 31 (2) (2007) 95-124.

[76] D. M. Koupaei, F. Hashemi, V. Tabard-Fortecoëf, and U. Passe, "Development of a Modelling Framework for Refined Residential Occupancy Schedules," FiftySixth Annu. Rep., p. 68, 2019.

[77] E. De Vos, H. Heynen, Shaping popular taste: The Belgian farmers' association and the fermette during the 1960s-1970s, Home Cult. 4 (3) (2007) 237-259.
[78] E. De Vos, "De fermette in Vlaanderen. Architecten, de overheid, het middenveld en enkele bewoners over deze droomwoning tijdens de jaren'60-'70," Van Mensen En Dingen Tijdschr. Voor Volkscult. Vlaan., vol. 6, no. 3-4, 2008.

[79] N. Janssens, Afbetaald, niet afgeschreven: de fermette, PHL University College, Hasselt, Belgium, 2011.

[80] L. Georges, C. Massart, G. Van Moeseke, A. De Herde, Environmental and economic performance of heating systems for energy-efficient dwellings: Case of passive and low-energy single-family houses, Energy Policy 40 (2012) 452464.

[81] TNS, Het energiebewustzijn en -gedrag van de Vlaamse huishoudens, Vlaams Energieagentschap (2015).

[82] IP Belgium, “Life Observer 2018, Observons le temps des Belges.” 2018.

[83] Gfk, "Possession et mise au rebut d'équipements électr(on)iques en 2017 Ménages belges : mesure 2," Recupel, Brussels, Belgium, 2018.

[84] ISO 17772-1, "ISO 17772-1: Energy performance of buildings - Indoor environmental quality. Part 1: Indoor environmental input parameters for the design and assessment of energy performance in buildings".," 2017.

[85] ISO 17772-2, "ISO 17772-2: Energy performance of buildings - Overall energy performance assessment procedures. Part 2: Guideline for using indoor environmental input parameters for the design and assessment of energy performance of buildings.," 2018.

[86] G. Verbeeck and W. Ceulemans, "Analyse van de EPC Databank: Resultaten tot en met 2012," Steunpunt Wonen, Leuevn, Belgium, 9789088360503, 2015.

[87] ICEDD, "Bilan Energetique de la Wallonie: Secteur Domestique et equivalents," Service Public de Wallonie, Namur, Belgium, 2012.

[88] K. Jespers et al., "Energy consumption survey for Belgian households," Boeretang Vito, 2012.

[89] S.P. Corgnati, E. Fabrizio, M. Filippi, V. Monetti, Reference buildings for cost optimal analysis: Method of definition and application, Appl. Energy 102 (2013) 983-993.

[90] S. Attia, Spatial and behavioral thermal adaptation in net zero energy buildings: an exploratory investigation, Sustainability 12 (19) (2020) 7961.

[91] M.I. Abreu, R.A. de Oliveira, J. Lopes, Younger vs. older homeowners in building energy-related renovations: Learning from the Portuguese case, Energy Rep. 6 (2020) 159-164

[92] R. Das, R. Richman, C. Brown, Demographic determinants of Canada's households' adoption of energy efficiency measures: observations from the Households and Environment Survey, 2013, Energy Effic. 11 (2) (2018) 465482.

[93] M. Hamdy, K. Sirén, S. Attia, Impact of financial assumptions on the cost optimality towards nearly zero energy buildings-A case study, Energy Build. 153 (2017) 421-438. 